\title{
Sticky Wage Models and Labor Supply Constraints*
}

\author{
Zhen Huo \\ José-Víctor Ríos-Rull \\ Yale University \\ University of Pennsylvania \\ UCL, CAERP, CEPR, NBER
}

Wednesday $1^{\text {st }}$ May, 2019

\begin{abstract}
In New Keynesian models with sticky wages à la Calvo or with wage adjustment costs à la Rotemberg, the quantity of labor is solely determined by the demand side. Unions with monopsony power set the wage above what it takes to make agents work. When wages are sticky a change of circumstances may make the demand for labor higher than agents' willingness to work. The literature implicitly assumes that the markup of wages over the willingness to work is large enough to ensure that workers always comply with the quantity of labor demanded. In this paper, we explore the extent to which this is the case and find that workers are required to work against their will between $15 \%$ and $30 \%$ of the time with a 5\% wage markup (less so with higher markups and with Rotemberg adjustment wage costs). Moreover, when we use in Calvo settings, as proposed by traditional theory (Drèze (1975)), the minimum of the demand and supply of labor instead of the demand-determined quantity, we find that the typical parametrization yields a variance of hours around 25\% lower (depending on the particular model). We estimate an approximated Drèze equilibrium in a state-of-the-art DSGE model and find that it yields answers that are sharply different from the demand-determined allocation. We conclude that when working with sticky wage economies, especial attention should be paid to the possible violations of the labor supply constraint, the condition that the amount of labor cannot be larger than what agents are willing to work.
\end{abstract}

Keywords: Sticky wages, New Keynesian model, Drèze equilibrium, Monetary policy

JEL classifications: E20, E32, E37, E52

*Ríos-Rull thanks the National Science Foundation for Grant SES-1156228. We are thankful for discussions with V.V. Chari, Jean-Jacques Herings, Patrick Kehoe, Ellen McGrattan and Frank Schorfheide. 


\section{Introduction}

In New Keynesian models with sticky wages à la Calvo or à la Rotemberg, the quantity of labor is solely determined by the demand side, implicitly assuming that households are always willing to work at whatever wage rate is specified, implicitly assuming that that the amount of labor is not larger than what agents are willing to work (what we refer to as the labor supply constraint) is not violated. Unions with monopsony power set wages above agents' marginal willingness to work, which provides a cushion that accommodates the effects of various shocks on the demand and supply of labor. If the shocks to the economy are not too large, the cushion is sufficient to guarantee that households happily accommodate the quantity of labor required. In this paper we document that the cushion is too small in popular DSGE models: demanddetermined labor often implies that some of the labor is provided against the will of the workers, a violation of the principle of voluntary exchange.

What is the natural alternative to the violation of the labor supply constraint? Here we have taken the strict position of staying within the two types of models that we explore, rather than proposing a change of model. In the Calvo model trade occurs at non-market clearing prices. For these type of environments, Drèze (1975), following the notion of disequilibrium modeling of Barro and Grossman (1971) and Malinvaud (1977), posed that the amount traded is the minimum of the quantities supplied and demanded and that the agents are aware of the limitation in the availability of the trades. ${ }^{1}$ The Drèze equilibrium provides an outcome that satisfies individual rationality without changing any feature of the environment and hence we think that the it is the natural equilibrium concept when wages are deemed to be fixed, as they are in sticky wage à la Calvo models. For the Rotemberg model, we think that the obvious alternative to ignoring the labor supply constraint is to let the unions internalize the constraint when they set prices, automatically inducing that the constraint is not violated.

We start our analysis by first substituting the demand-determined quantity of labor that the log-linearization procedure delivers with the minimum of the quantity of labor demanded and the quantity that agents would like to work. We refer to this quantity as voluntary ex-post aggregate labor or just ex-post labor. ${ }^{2}$ The comparison between the two series tells us whether some agents are working against their will in demanddetermined allocations. The ex-post labor is not part of an equilibrium (Drèze or otherwise), since agents made their decisions based on the demand-determined quantity of labor, but it does give us a preliminary account of the extent to which the demand-determined allocation is consistent with agents not working against their will.

\footnotetext{
${ }^{1}$ This requires that all firms internalize that they are treated equally when facing limited labor supply. We can see this as the result of assuming that firms send bids and that the available workers are equally distributed between all firms. That firms understand this is consistent with the model. An alternative that would add a lot of complexity without any substance is to pose a randomization mechanism.

${ }^{2}$ The calculation of ex-post labor is not a trivial endeavor: Calvo pricing implies that many different wages coexist at any point in time depending on the exact period when the wage was last set, and there is a different quantity of labor associated to each one of those wages.
} 
We carry out this comparison in two of the most standard models of the New Keynesian literature: Altig et al. (2011) and Smets and Wouters (2007). With Calvo pricing we find that the properties of the two measures of labor are quite different: In the Altig et al. (2011) model, the fraction of workers with labor supply constraint being violated varies from $19 \%$ to almost zero $(.3 \%)$ as the wage markup moves from $5 \%$ to $25 \%$. The variance of labor shrinks by $15 \%$ for a wage markup of $15 \%$ when we move from the demand-determined to the ex-post quantity of labor. In the Smets and Wouters (2007) model, wage markup shocks are important in accounting for wage and labor movements, but their magnitude and structural interpretation are controversial (as we discuss below). Therefore, we look at versions with and without these shocks. With wage markup shocks, the fraction of workers that have their labor supply constraint violated varies from $45 \%$ to $16 \%$ as the wage markup moves from $5 \%$ to $25 \%$. In expansions, ex-post labor shrinks so much so that the volatility actually becomes larger than that in the demanddetermined case. With a $15 \%$ wage markup, the variance increases by $50 \%$. When wage markup shocks are excluded, the fraction of workers that have their labor supply constraint violated varies from $32 \%$ to $2 \%$ as the wage markup goes from $5 \%$ to $25 \%$. The variance of labor is in $15 \%$ smaller in the demand determined model for a wage markup of $15 \%$.

Within the Rotemberg wage setting, the magnitude of the differences is still noticeable, but somewhat smaller: in the Altig et al. (2011) model, the frequency of the labor supply constraint violation is $5 \%$ with a $5 \%$ wage markup (and close to zero for larger markups), while the variance of labor is $10 \%$ smaller for the ex-post labor. In the Smets and Wouters (2007) model with wage markup shocks, the frequency of the violation of the labor supply constraint is $36 \%$ with a $5 \%$ wage markup and still $6 \%$ with a $25 \%$ markup. The variance of labor is also smaller for the ex-post labor, between $15 \%$ and $20 \%$ smaller, for a $5 \%$ wage markup depending on whether we include all shocks or not.

Ensuring that the labor supply constraint is not violated, either by using the Drèze equilibrium in the Calvo model or by having the unions internalize the constraint in the Rotemberg model has severe computational challenges. ${ }^{3}$ For this reason we propose an equilibrium approximation strategy that we use in both types of models. We verify in a simpler class of New Keynesian models (wage rigidity either a la Taylor or la Rotemberg and no bells and whistles in other dimensions) that the non-approximated equilibria and the approximated equilibria are very similar. This gives us confidence on the reliability of the findings that we obtain with the approximated equilibria in medium scale DSGE models with Calvo and Rotemberg prices.

We proceed to estimate a version of the Altig et al. (2011) economy with Calvo pricing under the approximated Drèze equilibrium, and we find that the economic properties are very different in the demanddetermined solution than when the labor supply constraint is required to be satisfied. The relative importance of the various shocks changes dramatically, with neutral technology shocks accounting for $71 \%$ of the variance of labor instead of the $13 \%$ obtained with the demand-determined solution. Moreover,

\footnotetext{
${ }^{3}$ The labor supply constraint is binding occasionally, which requires the model to be solved using global method with a large number of state variables.
} 
neutral technology shocks tend to have larger but less persistent innovations, a necessary feature to induce workers to increase their labor despite facing low wages. The estimates of the Drèze equilibrium imply a much higher wage rigidity. These features of the estimates under the Drèze equilibrium are somewhat inconsistent with reduced form VAR evidence and we do not consider this model an empirical success.

Further, because we also find that the approximations, both for the Drèze equilibria with Calvo pricing and for the union problem with Rotemberg pricing, are very close to the voluntary ex-post labor solutions, we are very confident that the latter series give us an accurate picture of the equilibria when the labor supply constraint is not violated.

Our conclusions are clear: the labor supply constraint in standard DSGE models with sticky wages can be frequently violated, and using demand-determined labor yields answers that are quite different from those that respect the labor supply constraint associated to agents not working more than what they want to.

Though we document that the demand-determined allocation in the sticky wages environment is questionable, the Drèze equilibrium in the Calvo wage setting is not the only alternative to address this type of issues. One could, for instance, assume that when the demand determined allocation is larger than the supply, wages could be reset (as in Hall and Milgrom (2008)). Another alternative is to introduce search and matching frictions that provide rents to workers with an employment relation, and to pose that under some circumstances the firm may ask them to work more or less hours than what they would choose on their own. Obviously, the Rotemberg wage setting with unions that take into account the labor supply constraint is yet another alternative. We believe that these alternatives are interesting and relevant, but no matter what alternative is taken, our results suggest that addressing the issue of avoiding violating the supply constraint may not have innocuous consequences.

In this paper, we focus on the Drèze equilibrium for Calvo settings because it has the appealing feature that it maintains the same primitive environment as the original model, and we can directly explore the logical implications of the Calvo wage setting in contrast to its demand-determined allocation. This exercise can be theoretically interesting by itself, and it extends the original Drèze equilibrium literature to a dynamic decision problem. The construction of voluntary ex-post labor and the approximated Drèze equilibrium can be quantitatively relevant because they provide practitioners of DSGE models a simple tool to examine whether the laobr supply constraint is violated or not in their own models. For the Rotemberg wage setting we impose that the unions internalize the labor supply constraint which also maintains the physical environment of model.

Related Literature The central notion that we highlight in this paper is that agents should not work against their will, and that this implies a labor supply constraint that should be thought of as a participation constraint. Similar ideas have already been explored in the literature. Hall (2005) develops a search model with sticky wages to account for the observed labor fluctuations. The wage is reset only if it hits the 
boundary of the bargaining set which is between the minimum wage acceptable to the worker and the maximum wage acceptable to the employer. The workers' participation constraint has to be respected. In a similar fashion, Gertler et al. (2008) and Gertler and Trigari (2009) explore a search model with Calvostyle sticky wages, and whether the bargaining set is violated or not is checked ex-post. It is generally true that the bargaining set is large enough to accommodate Calvo-type sticky wages when agents are only subject to aggregate shocks, but it remains a question whether the bargaining set is large enough when agents also face idiosyncratic shocks. Recently, Christiano et al. (2013) develop a quantitative model in which the wage is determined by alternating-offers bargaining, a variant of Hall and Milgrom (2008), a mechanism that introduces wage inertia endogenously, and is free of the concern on violating the participation constraint.

It can be argued along the lines of Barro (1977), that the form of wage rigidity in the Calvo model that the Drèze equilibrium maintains, is inconsistent with rational behavior, ${ }^{4}$ and that the Calvo assumption should be changed. A possible alternative to the strict Calvo pricing rigidity assumption could be to specify additional circumstances under which prices or wages could change (violation of the labor supply constraint is one them). We take this possibility as a change of the physical environment and hence we choose not to pursue it in this paper. That being said, note that in Rotemberg models wages are reset every period, which is not subject to the Barro (1977) critique. As a result, the Calvo setting and the Rotemberg setting could be potentially viewed as two extreme benchmarks for other wage setting protocols when incorporating wage rigidities.

Our paper focuses on the willingness of agents to work, but a similar argument can also be made on the willingness of firms to produce goods at a fixed price. For example, Corsetti and Pesenti (2005) emphasize that firms should only produce if the ex-post price markup is larger than one. Bills (2004) and Alessandria et al. (2010) consider firms' inventory stockout problems, where firms' sales have to be the minimum of the goods demanded and their existing inventory. Michaillat and Saez (2015) combine nominal rigidity with matching frictions in both goods and labor markets, where supply and demand jointly determine the outcome via affecting market tightness.

Van der Laan (1980), Kurz (1982), Dehez and Drèze (1984), Drèze (1997), and Citanna et al. (2001) are all related Drèze (1975)'s original work, and study the properties of supply-constrained economy and explore the connection between price distortion and coordination failure. Herings $(1996,2014)$ extend Drèze (1975)'s work to settings with more flexible primitives and to dynamic environments. Bénassy (1993) compares the original Drèze equilibrium with other closely related disequilibrium concepts, and explore their implications in a static monetary economy with fixed prices and a fixed wage. Our paper differs from the previous literature in two ways. First, the market structure in our paper is monopolistic competition instead of perfect competition, therefore, in periods where the wages can be reset, they will be set by

\footnotetext{
${ }^{4}$ Trujillo (1985), on the other hand, argued that rationality of conjectures can be defended and suffices to yield existence of equilibrium.
} 
forward-looking unions rather than the market. ${ }^{5}$ Second, the previous literature emphasized equilibrium existence and multiplicity, while our paper explores the quantitative properties in a state-of-the-art DSGE model.

We discuss the implicit assumption made in New Keynesian models when there is trade at non-marketclearing prices in Section 2 in the context of a model with wage setting à la Calvo. We proceed to explore in Section 3 the extent to which agents work against their will-what we jocularly label as slavery-in standard New Keynesian models (versions of Altig et al. (2011) and Smets and Wouters (2007)) and conclude that it happens too often to simply ignore. Section 4 discusses what we think is the appropriate equilibrium concept for economies with wage settings à la Calvo, the Drèze equilibrium (Drèze (1975)), and compares its properties with those of the demand-determined allocation used in New Keynesian models and with those of an approximation to the Drèze equilibrium in various economies that we can solve. We then proceed to estimate a version of the Altig et al. (2011) model using the approximated Drèze equilibrium and we show that we obtain quite different estimates than those obtained when using demand-determined allocations in Section 5. Section 6 poses wage settings a la Rotemberg and explores the extent to which the labor supply constraint is violated. Section 7 concludes by arguing that the approximation to the Drèze equilibrium should be used in lieu of the demand-determined equilibrium when studying environments with sticky wages. Various Appendices complete the paper: Appendix A provides the details of the estimation of Altig et al. (2011); Appendix B adds the details of the specification of the Smets and Wouters (2007) model; Appendix C looks at the labor supply constraint in the model of Galí et al. (2012); Appendix D provides the details of the global method when solving the Drèze Equilibrium in a staggered wage economy.

\section{The Labor Market in New Keynesian Models à la Calvo}

We pose a typical New Keynesian model with sticky wages, first introduced by Erceg et al. (2000). There is a continuum of differentiated labor varieties $n_{i}, i \in[0,1]$, which firms combine into a final labor input $n$ for production using a Dixit-Stiglitz aggregator with elasticity of substitution $\epsilon_{w}$ :

$$
n=\left[\int n_{i}^{\frac{\epsilon_{W}-1}{\epsilon_{W}}} d i\right]^{\frac{\epsilon_{W}}{\epsilon_{W}-1}} .
$$

The wage $w_{i}$ is set by unions that are specific to each labor variety $i$. Firms take all wages as given. Cost minimization, given wages and total labor $n$, yields demand schedules for each labor variety $i$,

$$
n_{i}=\left(\frac{w_{i}}{w}\right)^{-\epsilon_{w}} n
$$

where $w$ is an aggregate wage index $w=\left[\int w_{i}^{1-\epsilon_{w}} d i\right]^{\frac{1}{1-\epsilon_{w}}}$ that satisfies $\int w_{i} n_{i} d i=w n$.

\footnotetext{
${ }^{5}$ Bénassy (1993) also considers the case where private agents set the prices and wages in a static environment, and in our paper agents need to solve a more complicated dynamic pricing problem.
} 
A representative household consists of a continuum of workers, each one with different labor variety $i$ that enjoys the same consumption level. The household's utility is given by

$$
\mathbb{E}_{0}\left\{\sum_{t=0}^{\infty} \beta^{t}\left(u\left(c_{t}\right)-\int_{i} v\left(n_{i, t}\right) d i\right)\right\}
$$

The union sets the wage to maximize agents' utility. The opportunity to reset the wage occurs with probability $1-\theta_{w}$ (à la Calvo) every period. The union's problem is

$$
\begin{array}{cc}
\max _{w_{i, t}^{*}} & \mathbb{E}_{t}\left\{\sum_{k=0}^{\infty}\left(\beta \theta_{w}\right)^{k}\left[u^{\prime}\left(c_{t+k}\right) \frac{w_{i, t}^{*}}{p_{t+k}} n_{i, t+k}-v\left(n_{i, t+k}\right)\right]\right\}, \quad \text { subject to } \\
n_{i, t+k}=\left(\frac{w_{i, t}^{*}}{w_{t+k}}\right)^{-\epsilon_{w}} n_{t+k} .
\end{array}
$$

The first-order condition is

$$
\mathbb{E}_{t}\left\{\sum_{k=0}^{\infty}\left(\beta \theta_{w}\right)^{k}\left[n_{i, t+k} u^{\prime}\left(c_{t+k}\right)\left(\frac{w_{i, t}^{*}}{p_{t+k}}-\frac{\epsilon_{w}}{\epsilon_{w}-1} \frac{v^{\prime}\left(n_{i, t+k}\right)}{u^{\prime}\left(c_{t+k}\right)}\right)\right]\right\}=0 .
$$

Although not stated explicitly, this problem assumes that firms can choose any quantity that they want of each labor variety, which requires that workers comply. Note that the worker is not choosing how much to work. If it did, it would choose $\ell_{i}$ to equate the real wage to the marginal rate of substitution (the standard intratemporal Euler condition):

$$
\frac{w_{i, t}}{p_{t}}=\frac{v^{\prime}\left(\ell_{i, t}\right)}{u^{\prime}\left(c_{t}\right)}
$$

We refer to the $\ell_{i}$ that solves equation (7) as the optimal labor supply under wage $w_{i}$.

In the absence of wage rigidity $\left(\theta_{w}=0\right)$, the union sets the wage every period and condition (6) becomes

$$
\frac{w_{i, t}^{*}}{p_{t}}=\frac{\epsilon_{w}}{\epsilon_{w}-1} \frac{v^{\prime}\left(n_{i, t}\right)}{u^{\prime}\left(c_{t}\right)}
$$

i.e. marginal revenue equals the marginal rate of substitution, or in standard parlance, the real wage is set to equal the marginal rate of substitution multiplied by the wage markup $\frac{\epsilon_{w}}{\epsilon_{w}-1}$. Standard values for the elasticity of substitution ensure that what we call the labor supply constraint, $\ell_{i} \geq n_{i}$, that agents would like to work more than the quantity chosen by firms, is not violated and hence that the determination of the equilibrium quantity of labor via the quantity demanded is justified.

Under wage stickiness, however, the wage set by equation (6) may imply an optimal supply of labor 
$\ell_{i, t}<n_{i, t}$, violating the labor supply constraint. In this case, the assumption that labor is demanddetermined implies that workers are working against their will (i.e., slavery).

What is the correct notion of equilibrium within the Calvo model in the context of a non-market-clearing price? Drèze (1975), following the disequilibrium models of Barro and Grossman (1971) and Malinvaud (1977), argued that it should be the minimum of supply and demand: trades should be voluntary. This is the notion that we follow in this paper.

Hours versus Bodies But is there anything really inappropriate about posing a model where agents work more than desired? Labor varies because of both changes in hours per worker and changes in the number of workers. An argument could be made that workers may not be free to choose the number of hours that they work without losing their jobs, and therefore our notion that workers should not work against their will only applies to the extensive margin. In that case, it is only when dealing with the extensive margin that the argument that the correct equilibrium condition is the minimum of the quantity supplied and the quantity demanded is really strong.

A recent wave of New Keynesian models (Galí (2011); Galí et al. (2012)) have incorporated unemployment by looking explicitly at changes in the extensive margin. In these models, households have a continuum of workers represented by the unit square and indexed by a pair $(i, j) \in[0,1] \times[0,1]$. The $i$-dimension represents the type of labor service, while the $j$-dimension determines the worker's disutility from work, which equals $j^{\gamma}$ if it is employed and zero if unemployed or outside the labor force. The household's utility is now given by

$$
E_{0} \sum_{t=0}^{\infty} \beta^{t}\left(u\left(c_{t}\right)-\int_{i} \int_{0}^{n_{i, t}} j^{\gamma} d j d i\right)=E_{0} \sum_{t=0}^{\infty} \beta^{t}\left(u\left(c_{t}\right)-\int_{i} \frac{n_{i, t}^{1+\gamma}}{1+\gamma} d i\right) .
$$

An individual worker $(i, j)$ takes the household's consumption level and the labor market conditions as given and will find it optimal to participate in the labor market if and only if

$$
u^{\prime}\left(c_{t}\right) \frac{w_{i, t}}{p_{t}} \geq j^{\gamma}
$$

Hence, the measure of workers in sector $i$ who want to work is $\ell_{i}$, which solves ${ }^{6}$

$$
u^{\prime}\left(c_{t}\right) \frac{w_{i, t}}{p_{t}}=\ell_{i, t}^{\gamma}
$$

We can (as Galí (2011) and Galí et al. (2012) do) define the unemployment rate as $u_{t}=\ell_{t}-n_{t}$. Moreover, in the absence of wage rigidities or in a steady state, the natural rate of unemployment rate $u^{n}$ and the

\footnotetext{
${ }^{6}$ Note that when the labor disutility function is $v(n)=\frac{n^{1+\gamma}}{1+\gamma}$, then equation (11) coincides with equation (7).
} 
union's market power are linked by

$$
\frac{1}{\epsilon_{w}-1} \approx \gamma u^{n}
$$

In these models, labor supply is determined by the number of agents willing to work. When labor demand exceeds labor supply (i.e.,s, $n_{i}>\ell_{i}$ ), some agents are required to work against their will (hence our jocular use of the term slavery). More dramatically, if labor demand exceeds the total population, $n_{i}>1$, firms would be hiring workers that do not exist. It is in this type of model where the argument that the labor supply constraint should not be violated has the strongest appeal.

\section{Are Agents Working Against Their Will in Popular New Keynesian Models?}

We now turn to the quantitative exploration of the extent to which agents work against their will by comparing the properties of labor in our versions of the standard Altig et al. (2011) and Smets and Wouters (2007) environments with the level of labor in those economies that would be the minimum of supply and demand. Altig et al. (2011) augment Christiano et al. (2005) with neutral and embodied technology shocks, while Smets and Wouters (2007) also include preferences shocks, wage and price markup shocks and government spending shocks. We use both of these models because they are de facto the standard New Keynesian models (more details about these models are in Appendices A and B). In these two models, labor is interpreted as hours worked and it could be argued that workers are implicitly obliged to work some periods more than they wish. For this reason, we also provide a discussion in Appendix C of the Gali et al. (2012) model where a unit of labor has the meaning of a worker. As we show there, the quantitative findings are very much in line with the findings of this Section.

To find out the extent to which agents are working against their will, we start solving and simulating the models as in the New Keynesian literature by assuming that labor is demand-determined. With the simulated history of aggregate wages and the aggregate labor demand, we construct the cross-sectional desired labor supply and labor demand for different labor varieties. We then construct our notion of voluntary ex-post labor by computing the minimum of the quantity of labor demanded and the quantity that agents would like to work for each wage/cohort and then adding them up across cohorts every period. The larger the difference between the demand-determined labor and the voluntary ex-post labor the more severe the violation of the labor supply constraint. Still, the voluntary ex-post labor is not the labor in a Drèze equilibrium because the latter requires that agents are aware of the equilibrium condition, and also of the implied adjustments in all the other model variables. However, this shortcut is useful in detecting whether we need to worry about this issue at all.

We discuss the details of how to construct the voluntary ex-post labor in Section 3.1. This is not a trivial endeavor, because at any point in time, there are a large number of different wages, each one of them affecting a different group of workers who have different preferred labor choices. The quantitative analysis 
is in Section 3.2.

\subsection{The Determination of the Voluntary Ex-post Aggregate Labor}

To determine the desired labor supply of workers we have to keep track, not only of the aggregate wage index of the economy, but also of the wages for all labor varieties $i$. Fortunately, this can be done by noting that all labor varieties that set the wage in a given period choose the same wage. We describe our procedure in three steps.

Step 1: Construct the cross-sectional wage distribution The measure of workers that can reset their wages in the current period is $\mu_{0}=1-\theta_{w}$, while the measure of workers with wage reset $\tau$ periods before is $\mu_{\tau}=\left(1-\theta_{w}\right) \theta_{w}^{\tau}, \quad \tau=0,1,2, \ldots$, so $\mu_{\tau}$ becomes negligible for $\tau$ large enough.

The simulation of the log-linearized model with demand-determined labor yields the sequence of the aggregate wage index $\left\{w_{t}\right\}$, which evolves according to

$$
w_{t}=\left[\int w_{i, t}^{1-\epsilon_{w}} d i\right]^{\frac{1}{1-\epsilon_{w}}}=\left[\theta_{w}\left(w_{t-1}\right)^{1-\epsilon_{w}}+\left(1-\theta_{w}\right)\left(w_{t}^{*}\right)^{1-\epsilon_{w}}\right]^{\frac{1}{1-\epsilon_{w}}},
$$

where $w_{t}^{*}$ is the newly set wage in period $t$. Since we already have the aggregate wage sequence $\left\{w_{k}\right\}_{k=0}^{t}$, we can easily calculate the sequence of newly set wages $\left\{w_{k}^{*}\right\}_{k=0}^{t}$ using Equation (13). The wages prevailing in period $t$ are then $\left\{w_{t-\tau}^{*}\right\}$, with corresponding measure $\mu_{\tau}, \tau \geq 0$.

Step 2: Construct cross-sectional labor Demand and labor Supply Given aggregate labor $\left\{n_{t}\right\}$, the labor demand for workers with wage rate $w_{t-\tau}^{*}$ is

$$
n_{\tau, t}=\left(\frac{w_{t-\tau}^{*}}{w_{t}}\right)^{-\epsilon_{w}} n_{t}
$$

Agents that face wage rate $w_{t-\tau}^{*}$, have an optimal choice of labor given by the $\ell_{\tau, t}$ that solves

$$
\frac{w_{t-\tau}^{*}}{p_{t}}=\frac{v^{\prime}\left(\ell_{\tau, t}\right)}{u^{\prime}\left(c_{t}\right)}
$$

Aggregating both series over cohorts or wage groups, we obtain the aggregate demand for labor, ${ }^{7} n_{t}=$ $\left[\sum_{\tau=0}^{\infty} \mu_{\tau}, n_{\tau, t}^{\frac{\epsilon_{W}-1}{\epsilon_{W}}}\right]^{\frac{\epsilon_{W}}{\epsilon_{W}-1}}$, and the aggregate supply of labor $\ell_{t}=\left[\sum_{\tau=0}^{\infty} \mu_{\tau}, \ell_{\tau, t}^{\frac{\epsilon_{W}-1}{\epsilon_{W}}}\right]^{\frac{\epsilon_{W}}{\epsilon_{W}-1}}$.

\footnotetext{
${ }^{7}$ Under log-linearization, an approximation error results in a negligible difference between aggregate labor and this expression.
} 
Step 3: Construct aggregate labor Voluntary ex-post labor, $e_{t}^{p}$ (we use the superscript $p$ to denote that it is an ex-post quantity), is the minimum of supply and demand at each wage, ${ }^{8}$

$$
e_{t}^{p}=\left[\sum_{\tau=0}^{\infty} \mu_{\tau}\left(\min \left\{n_{\tau, t}, \ell_{\tau, t}\right\}\right)^{\frac{\epsilon_{W}-1}{\epsilon_{W}}}\right]^{\frac{\epsilon_{W}}{\epsilon_{W}-1}},
$$

We want to emphasize that $e_{t}^{p}$ is not an equilibrium object, both because when making decisions, neither firms nor unions or workers take this factor into consideration, and because the implied path of consumption, investment, and capital is that associated with the demand-determined allocation. However, it allows us to check whether the extent to which the labor supply constraint is violated. If $n_{\tau, t}<\ell_{\tau, t}$ all the time, then $n_{t}=e_{t}^{p}$ and it is correct to use demand-determined labor. If instead, $n_{\tau, t}>\ell_{\tau, t}$ happens frequently and the difference between $n_{\tau, t}$ and $\ell_{\tau, t}$ is large, then $n_{t}$ will be substantially different from $e_{t}^{p}$ and the answers obtained by models that use demand-determined quantities of labor are questionable.

\subsection{Quantitative Analysis of the Altig et al. (2011) and Smets and Wouters (2007) Models}

Sticky wage models lack a straight identification of the steady-state wage markup, which affects the dynamics of labor and wages only through the slope of the wage Phillips curve that also depends on other deep parameters. The parameter $\epsilon_{w}$ that determines the steady-state markup is typically set exogenously. For example, Altig et al. (2011) sets the wage markup to be 5\%, Smets and Wouters (2007) sets its value to $50 \%$, and most DSGE models set this value between $5 \%$ to $25 \% .{ }^{9}$ Galí (2011) uses the relationship between the wage markup, the unemployment rate and the Frisch elasticity in (12), and explores markups from $5 \%$ to $25 \%$ for an empirically relevant range of Frisch elasticity. ${ }^{10}$ In this paper we have chosen to estimate both of models, setting the wage markup to values in accordance with the recent literature, ranging from $5 \%$ to $25 \%$. For values larger than $25 \%$, the labor supply constraint turns out to be much less relevant.

The Labor Supply Constraint in the Altig et al. (2011) Model Figure 1 displays sample paths of the demand-determined labor $\left(n_{t}\right)$ and of the voluntary ex-post labor $e_{t}^{p}$ constructed as discussed in Section 3.1 for different wage markups. Note that demand-determined labor is always as large as the voluntary ex-post aggregate labor by construction. The difference between these two series is noticeable. Both series coincide in recessions, but the voluntary ex-post labor does not expand as much as the demand-determined labor in expansions. In fact, for a 5\% wage markup, the voluntary ex-post labor actually declines when the demand-determined labor expands. This is because the expansion takes place by asking low-paid workers

\footnotetext{
${ }^{8}$ Quantitatively, the difference between the Dixit-Stiglitz aggregator and the linear average labor is negligible.

${ }^{9}$ Lewis (1986) surveys the literature on the wage premium for workers in a union, which corresponds to the wage markup in the model, and the value is between $10 \%$ to $20 \%$. The steady-state wage markup is $5 \%$ in Christiano et al. (2005), $15 \%$ in Chari et al. (2002), and $20 \%$ in Levin et al. (2006).

${ }^{10}$ In an estimated version, Galí et al. (2012) obtain the steady-state wage markup with an value $18 \%$.
} 
to supply a huge amount of labor which is no longer possible if the workers can choose not to meet the demand. Also, the smaller the wage markup, the larger the differences between these two series as the average distance between labor demand and labor supply shrinks.
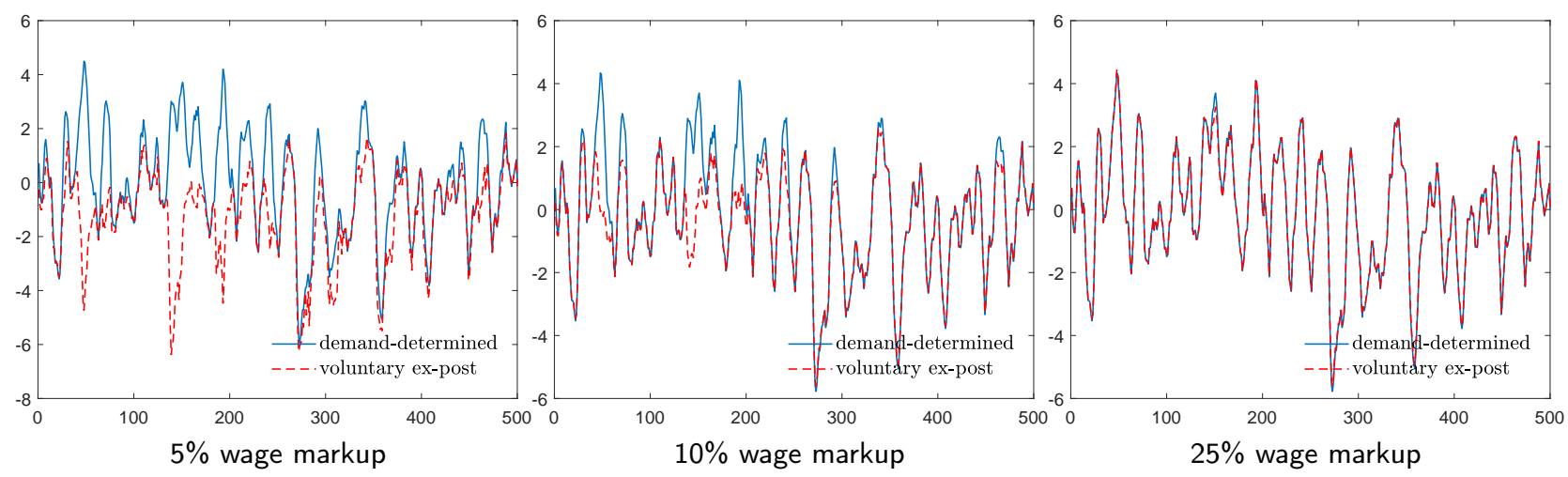

Figure 1: Demand-Determined and Voluntary Ex-Post Labor in Altig et al. (2011)

Table 1: Demand-Determined and Voluntary ex-post Aggregate Labor

\begin{tabular}{|c|c|c|c|c|c|c|c|c|}
\hline \multirow[b]{4}{*}{ Demand-Determined } & \multirow{3}{*}{ mean } & \multirow[b]{2}{*}{ var } & \multirow[b]{2}{*}{$\begin{array}{c}\text { corr with } \\
\text { output }\end{array}$} & \multicolumn{2}{|c|}{ Altig et al. (2011) } & \multirow[b]{2}{*}{ var } & \multirow[b]{2}{*}{$\begin{array}{c}\text { corr with } \\
\text { output }\end{array}$} & \multirow[b]{2}{*}{$\begin{array}{l}\% \text { labor } \\
\text { violation }\end{array}$} \\
\hline & & & & $\begin{array}{l}\% \text { labor } \\
\text { violation }\end{array}$ & mean & & & \\
\hline & & \multicolumn{3}{|c|}{$5 \%$ wage markup } & & \multicolumn{3}{|c|}{$10 \%$ wage markup } \\
\hline & - & 1.38 & 0.96 & 18.83 & - & 1.35 & 0.96 & 5.58 \\
\hline \multirow[t]{2}{*}{ Voluntary Ex-Post } & -1.41 & 0.97 & 0.42 & - & -0.45 & 0.94 & 0.84 & - \\
\hline & \multicolumn{4}{|c|}{$15 \%$ wage markup } & \multicolumn{4}{|c|}{$25 \%$ wage markup } \\
\hline Demand-Determined & - & 1.35 & 0.96 & 2.28 & - & 1.35 & 0.96 & 0.31 \\
\hline Voluntary Ex-Post & -0.15 & 1.18 & 0.93 & - & 0.00 & 1.33 & 0.96 & - \\
\hline
\end{tabular}

Notes: All the variables except the mean are logged and HP filtered except for the mean comparison. The column $\%$ labor violation corresponds to the average measure of workers whose labor supply constraint is violated.

Table 1 summarizes the relevant statistics to compare both labor series for the Altig et al. (2011) economy for wage markups ranging form $5 \%$ to $25 \%$. As discussed the violation of the labor supply constraint is more important the lower the wage markup. When the wage markup is $5 \%$ (the actual choice in Altig et al. (2011)), the voluntary ex-post labor is on average less than $1.41 \%$ lower than in the demand-determined. Almost $19 \%$ of labor is provided against the will of the workers. Perhaps, more importantly, the implied variance of the demand-determined labor series is $40 \%$ larger than that of the voluntary ex-post series and the correlation is more than twice as large. While for larger wage markups the differences are smaller, we 
find that even with a $15 \%$ wage markup the demand-determined labor series has a $14 \%$ larger variance than the voluntary ex-post labor series. For a $25 \%$ wage markup, the differences while positive are quantitatively negligible.

The Labor Supply Constraint in the Smets and Wouters (2007) Model Figure 2 displays sample paths of demand-determined labor and voluntary ex-post labor for the Smets and Wouters (2007) for a variety $(5 \%, 10 \%$ and $25 \%)$ of wage markups. We see that the differences are very large, especially for low wage markups. The left panel of Table 2 displays the relevant statistics for those two series. The results are even more dramatic than for the Altig et al. (2011) economy: the graphs tell us that the differences are large and that they can still be clearly seen with a $25 \%$ markup. We see that the fraction of the labor force for whom the labor supply constraint is violated is as high as $45 \%$ with a $5 \%$ markup but even with $16 \%$ with a $25 \%$ markup. The differences in the mean labor are also very large ranging from almost $7 \%$ to almost $1 \%$. The differences are really enormous for the variance of the two series, which now differ by a factor of 10 (for a 5\% wage markup), and unlike for the Altig et al. (2011) economy it is larger for voluntary ex-post labor. The reason is that for a small wage markup, voluntary ex-post labor sometimes shrinks to the point of moving in the opposite direction, and hence what is an expansion under demand-determined labor is a recession in terms of voluntary ex-post labor (note the much lower correlation with output). This reasoning also applies in accounting for the very low correlation between the voluntary ex-post labor and output. In this analysis, the labor supply constraint is severely violated in this economy, with the wage markup shock playing a central role in driving this result, so we look in more detail to the role played by this shock.
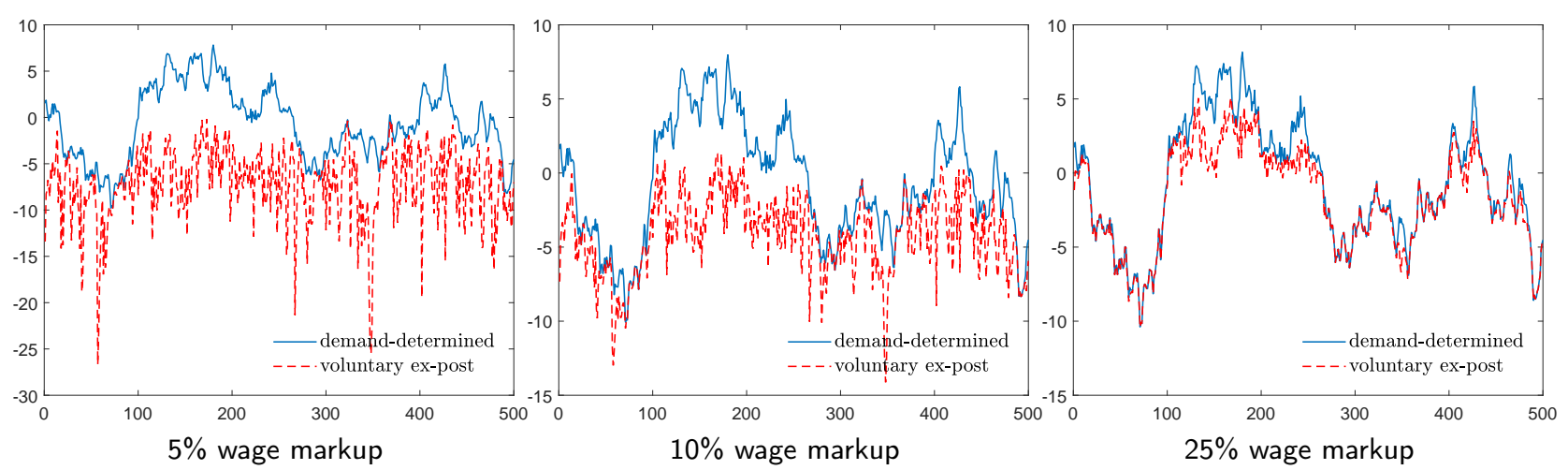

Figure 2: Sample Paths of Demand-Determined and Voluntary Ex-Post Labor in Smets and Wouters (2007)

Wage Markup Shocks in the Smets and Wouters (2007) Economy The variance of the wage markup shock reported is $25.87 \%$, quite a large value ${ }^{11}$ that makes the implied wage markup itself some-

\footnotetext{
${ }^{11}$ That this is a huge value is also emphasized by Chari et al. (2009).
} 
times close to zero or even become negative.
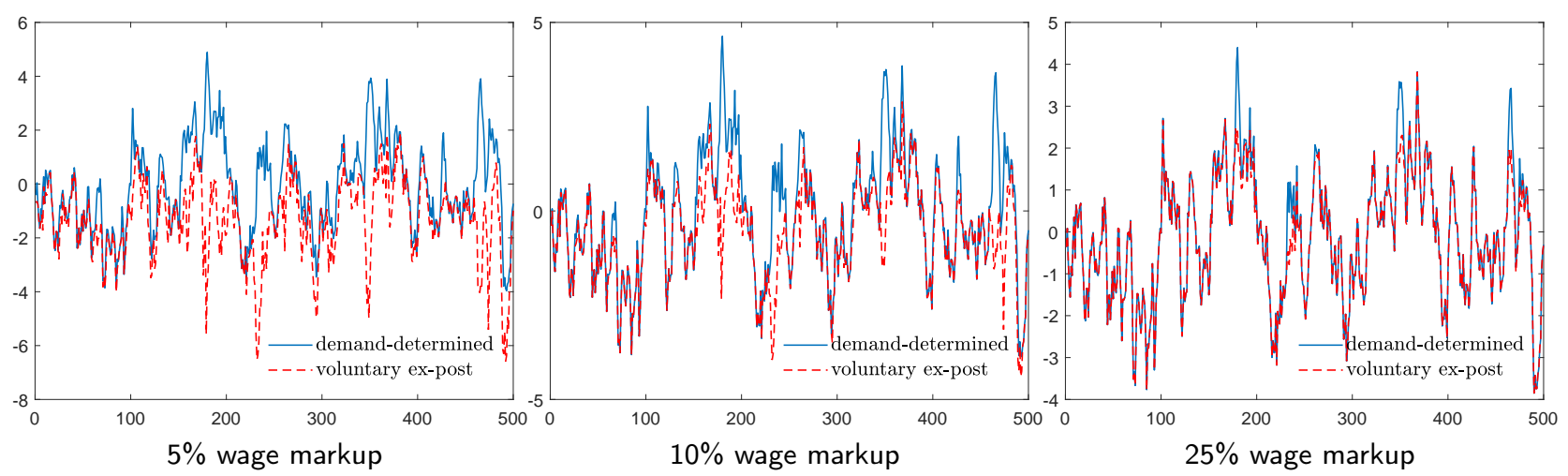

Figure 3: Sample Paths of Demand-Determined and Voluntary Ex-Post Labor in Smets and Wouters (2007) excluding Wage Markup Shocks

At a disaggregate level, the large volatility of markup shocks has some undesirable implications. Without log-linearization, the large variance of the shock implies implausibly large labor dispersion. Recall from eq. (2) that $n_{i, t}=\left(\frac{w_{i, t}}{w_{t}}\right)^{-\epsilon_{w, t}} n_{t}$. A negative wage markup implies that firms will be willing to demand more labor under a higher wage rate, which makes little economic sense. If the markup is positive but close to zero, then $\epsilon_{w, t}$ approaches to infinity, and as a result labor demand eq. (2) implies that almost all the labor is supplied by a tiny fraction of workers with the lowest wage, which is clearly counterfactual and the labor supply constraint is highly likely to be binding. ${ }^{12}$ The log-linearized version of this model partially gets around this issue by making the demand of labor of type $i$ independent of the actual realization of the markup shock: $\widehat{n}_{i, t}=-\epsilon_{w}\left(\widehat{w}_{i, t}-\widehat{w}_{t}\right)+\widehat{n}_{t}$, (where hats denote log-deviations from the steady state). However, the aggregate wage does depend on the aggregate wage markup leaving a channel through which this shock can generate by itself large violations of the labor supply constraint. ${ }^{13}$ To address this concern, we also examine the labor supply constraint in the Smets and Wouters (2007) economy without the wage markup shocks. Figure 3 shows a sample path without markup shocks of the demand-determined labor and the voluntary ex-post labor series. We see immediately that the two series are much closer to each other, indicating that indeed the problem of violating the labor supply constraint may be much smaller without the labor markup shock.

Table 2 compares the demand-determined labor with the ex-post labor with and without wage markup shocks. Things are quite different, yet even without the wage markup shocks the labor supply constraint is violated quite often; there is also a sizeable reduction of average hours worked and a weakening of the correlation between labor and output; and last but not least, there are important differences in the

\footnotetext{
${ }^{12}$ Moreover, for values of the wage markup close to zero in absolute value, the construction of the newly-set wage from eq. (13) may not even make economic sense as it may be a complex number.

${ }^{13}$ See Chari et al. (2009) for a discussion for different possible interpretations of the wage markup shocks.
} 
variance of the labor series. For middle markups $(10 \%, 15 \%)$ the variance of the demand-determined series is between $37 \%$ and $48 \%$ larger than the voluntary ex-post series. Curiously, for the $5 \%$ markup version of the economy the opposite is true and the variance of the voluntary ex-post labor is slightly larger than that of the demand-determined series. The reason for this is, again, that for a small wage markup, voluntary expost labor sometimes shrinks to the point of moving in the opposite direction than the demand-determined, and hence what is an expansion under demand-determined labor may be a recession in terms of voluntary ex-post labor as the much lower correlation with output indicates.

Table 2: Smets and Wouters (2007) Economy with and without Wage Markup Shock

\begin{tabular}{|c|c|c|c|c|c|c|c|c|}
\hline & \multicolumn{4}{|c|}{ w/ Wage Markup Shock } & \multicolumn{4}{|c|}{ w/o Wage Markup Shock } \\
\hline & mean & var & $\begin{array}{c}\text { corr with } \\
\text { output }\end{array}$ & $\begin{array}{l}\% \text { labor } \\
\text { violation }\end{array}$ & mean & var & $\begin{array}{l}\text { corr with } \\
\text { output }\end{array}$ & $\begin{array}{c}\% \text { labor } \\
\text { violation }\end{array}$ \\
\hline \multicolumn{9}{|c|}{$5 \%$ wage markup } \\
\hline Demand-determined & - & 1.16 & 0.81 & 44.57 & - & 1.02 & 0.80 & 31.63 \\
\hline Voluntary ex-post & -6.73 & 11.76 & 0.01 & - & -1.29 & 1.04 & 0.27 & - \\
\hline \multicolumn{9}{|c|}{$10 \%$ wage markup } \\
\hline Demand-determined & - & 1.14 & 0.81 & 37.73 & - & 0.98 & 0.79 & 12.95 \\
\hline Voluntary ex-post & -3.53 & 3.24 & 0.16 & - & -0.50 & 0.66 & 0.53 & - \\
\hline \multicolumn{9}{|c|}{$15 \%$ wage markup } \\
\hline Demand-determined & - & 1.13 & 0.81 & 29.98 & - & 0.96 & 0.79 & 5.79 \\
\hline Voluntary ex-post & -2.14 & 1.73 & 0.32 & - & -0.23 & 0.70 & 0.68 & - \\
\hline \multicolumn{9}{|c|}{$25 \%$ wage markup } \\
\hline Demand-determined & - & 1.12 & 0.81 & 16.38 & - & 0.94 & 0.78 & 1.57 \\
\hline Voluntary ex-post & -0.84 & 1.07 & 0.59 & - & -0.06 & 0.85 & 0.76 & - \\
\hline
\end{tabular}

Notes: All the variables except the mean are logged and HP filtered. The column \% labor violation corresponds to the average measure of workers whose labor supply constraint is violated.

Cross-sectional Dispersion of Labor across Sectors An implication of models with wage settings à la Calvo that is often ignored is that there is significant cross-sectional dispersion of hours across labor varieties $i$. In expansions, the increase in aggregate labor is mostly due to an increased labor demand for varieties that reset wages a while ago at a low level, and the varieties that reset wages more recently typically choose a high wage that can actually lead to a decline of the demand for their labor. The implied dispersion is especially large when the steady-state wage markup is relatively small. Figure 4 shows the cross-sectional distribution of hours for the Altig et al. (2011) and Smets and Wouters (2007) models for a 
$5 \%$ wage markup (without wage markup shocks). We see the large dispersion of the demand-determined labor and how the voluntary ex-post labor limits those varieties with high demand.

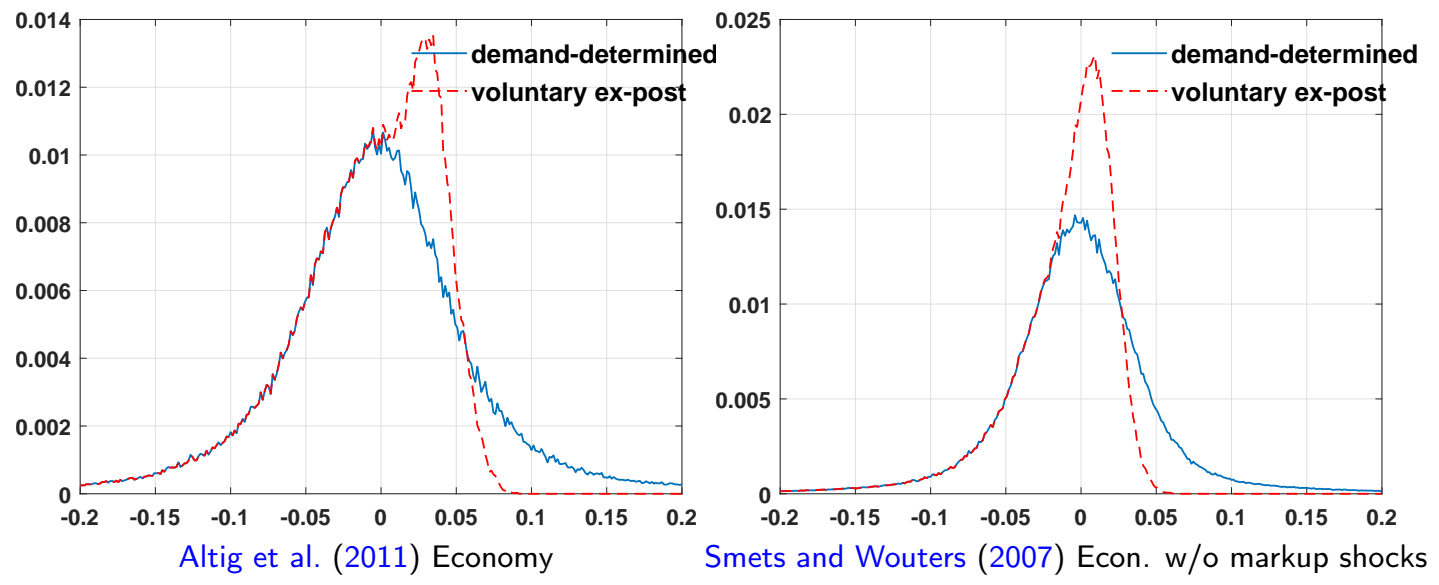

Figure 4: Cross-sectional Dispersion of Hours for a 5\% Markup

Table 3 also illustrates this point for a variety of wage markups by showing the standard deviations of the cross-sectional demand-determined sector-specific labor demands and of the cross-sectional voluntary ex-post sector-specific labor demands. The dispersion is much larger for all demand-determined labor varieties than for the voluntary ex-post labor varieties.

Table 3: Standard Deviation of Cross-Sectional Hours

\begin{tabular}{|c|c|c|c|c|c|c|c|c|}
\hline \multirow[b]{2}{*}{ Wage Markup } & \multicolumn{4}{|c|}{ Altig et al. (2011) } & \multicolumn{4}{|c|}{$\begin{array}{l}\text { Smets and Wouters (2007) } \\
\text { without markup shocks }\end{array}$} \\
\hline & $5 \%$ & $10 \%$ & $15 \%$ & $25 \%$ & $5 \%$ & $10 \%$ & $15 \%$ & $25 \%$ \\
\hline Demand-determined & 0.069 & 0.048 & 0.039 & 0.029 & 0.080 & 0.056 & 0.046 & 0.035 \\
\hline Voluntary ex-post & 0.046 & 0.039 & 0.035 & 0.029 & 0.048 & 0.041 & 0.038 & 0.033 \\
\hline
\end{tabular}

\section{Drèze Equilibrium}

So far, we have made the case that the use of demand-determined labor as the equilibrium condition is inappropriate because households want to work less quite often: the minimum of the amount of labor demanded and supplied (as standard theory considers the appropriate equilibrium condition) behaves very differently than the amount of labor demanded. However, the series that we have constructed (voluntary ex-post labor) is not an equilibrium object because it is constructed along a path defined by the demanddetermined labor and its associated series: output, consumption, investment, prices, wages, and so on. 
Moreover, the forecasts of agents are those of the demand-determined allocation. Therefore, we need to compute the Drèze equilibrium explicitly.

Unfortunately, log-linearization cannot be used to solve for the Drèze equilibrium. Global methods are needed given that the equilibrium condition is based on the min operator. Recent developments in computational economics that allow us to deal effectively with corner solutions, e.g. Guerrieri and lacoviello (2015) cannot be applied either: these methods require the corners or temporarily binding constraints to be predetermined (like the zero bound of nominal interest rates or the lower and upper bound of hours worked), whereas in our economies, the min operator applies to two endogenous variables. We discuss this issue in detail in Appendix D.1. Moreover, the number of state variables is effectively infinite because the whole set of existing wages is part of the state vector (even if truncating the number of periods that we keep track of we would still need many state variables). Global methods can only be used with a limited number of variables, which presents a problem.

Our strategy here is to explore the properties of the Drèze equilibrium in an economy that we can solve with global methods (a simplified version of the Altig et al. (2011) economy with staggered wages à la Taylor), and to compare its solution with a suitable simple approximation (effectively one where we impose feasibility, and maintain properties of the log-linearized solution but forgo the rationality of agents' expectations). We claim that the global solution and our approximation are close, and hence we argue that we can use the approximated solution to the Drèze equilibrium as we do in Section 5.

We now describe the simple model with staggered wage contracts (Section 4.1) and then describe an approximation to its solution that uses as a basis a log-linear approximation to the demand-determined equilibrium of the same economy (Section 4.2). We compare the quantitative properties of both objects in Section 4.3.

\subsection{The Drèze Equilibrium}

Consider an infinitely lived stochastic growth monetary economy. A representative household consists of a continuum of workers, each one with different labor variety $i$, that enjoy the same consumption level. The household's utility is given by

$$
\mathbb{E}_{0} \sum_{t=0}^{\infty} \beta^{t}\left(u\left(c_{t}\right)-\phi \int_{i} \frac{e_{i, t}^{1+\gamma}}{1+\gamma} d i\right),
$$

where $e_{i}$ is the labor of variety $i$. Households take prices and firms' profits as given, and their budget constraint is

$$
p_{t}\left(c_{t}+k_{t+1}-(1-\delta) k_{t}\right)+\frac{1}{R_{t}} b_{t+1}=r_{t}^{k} k_{t}+\int_{i} w_{i, t} e_{i, t} d i+b_{t}+\Pi_{t}
$$


Firms are competitive with Cobb-Douglas production technology $y_{t}=z_{t} k_{t}^{\alpha} e_{t}^{1-\alpha}$, where $e_{t}$ is the final labor used in production aggregated via a Dixit-Stiglitz technology

$$
e_{t}=\left[\int e_{i, t}^{\frac{\epsilon_{W}-1}{\epsilon_{W}}} d i\right]^{\frac{\epsilon_{W}}{\epsilon_{W}-1}},
$$

and total factor productivity (TFP) follows an $A R(1)$ process

$$
\log z_{t}=\rho_{z} \log z_{t-1}+\zeta_{t}^{z}, \quad \zeta_{t}^{z} \sim \mathbb{N}\left(0, \sigma_{z}^{2}\right)
$$

Unlike in standard New Keynesian models, labor market outcomes are determined by the minimum of supply and demand. We will introduce $\Phi_{t}\left(w_{i, t}\right)$ and $\Psi_{t}\left(w_{i, t}\right)$ below to denote the labor supply schedule and labor demand schedule as functions of wage rates. Individual firms and unions take them as given when making decisions. Because these functions also depend on the aggregate state, we use the time subscript to simplify notation, writing $\Psi_{t}$ and $\Phi_{t}$.

Firms are price takers and solve

$$
\begin{array}{rlr}
\max _{k_{t}, e_{t}, e_{i, t}} p_{t} z_{t} k_{t}^{\alpha} e_{t}^{1-\alpha}-r_{t}^{k} k_{t} & -\int w_{i, t} e_{i, t} d i \quad \text { subject to } \\
e_{t} & =\left[\int e_{i, t}^{\frac{\epsilon_{W}-1}{\epsilon_{W}}} d i\right]^{\frac{\epsilon_{W}}{\epsilon_{W}-1}}, \\
e_{i, t} & \leq \Phi_{t}\left(w_{i, t}\right)
\end{array}
$$

where $\ell_{i t}=\Phi_{t}\left(w_{i, t}\right)$ is the maximum amount of labor the firm can obtain of labor of variety $i$ under the wage rate $w_{i, t}$. In standard New Keynesian models, this last constraint is absent. ${ }^{14}$ The solution to the firms' problems satisfies

$$
\begin{aligned}
\frac{r_{t}^{k}}{p_{t}} & =\alpha z_{t} k_{t}^{\alpha-1} e_{t}^{1-\alpha} \\
e_{i, t} & =\min \left\{\left[\frac{w_{i, t}}{(1-\alpha) z_{t} k_{t}^{\alpha} n_{t}^{-\alpha} p_{t}}\right]^{-\epsilon_{w}} e_{t}, \Phi_{t}\left(w_{i, t}\right)\right\}, \\
e_{t} & =\left[\int e_{i, t}^{\frac{\epsilon_{w}-1}{\epsilon_{w}}} d i\right]^{\frac{\epsilon_{w}}{\epsilon_{W}-1}} .
\end{aligned}
$$

\footnotetext{
${ }^{14}$ Constraint (22) implicitly assumes that all firms internalize that they are treated equally when facing a limited labor supply. We can see this as the result of assuming that firms send bids and that the available workers are equally distributed between all firms. This interpretation is strictly consistent with the model. An alternative that would add a lot of complexity without any substance is to pose a randomization mechanism.
} 
Denote by $n_{i t}=\Psi_{t}\left(w_{i, t}\right)$ the desired labor demand in the absence of the quantity constraint. We have

$$
\Psi_{t}\left(w_{i, t}\right)=\left[\frac{w_{i, t}}{(1-\alpha) z_{t} k_{t}^{\alpha} e_{t}^{-\alpha} p_{t}}\right]^{-\epsilon_{w}} e_{t} .
$$

In this economy, there is a continuum of labor unions, each setting the wage of the type of labor that they represent, that maximize households' welfare given the behavior of all other parts of the economy. Workers cannot be made to work against their will, and the union takes into account that there is an upper bound on the amount of labor that will be provided in their sector. The union chooses a nominal wage that will be effective for $T^{w}$ periods:

$$
\begin{gathered}
\max _{w_{t}^{*}} \mathbb{E}_{t}\left\{\sum_{k=0}^{T^{w}-1} \beta^{k} u^{\prime}\left(c_{t+k}\right) \frac{w_{t}^{*}}{p_{t+k}} e_{i, t+k}-\frac{e_{i, t+k}^{1+\gamma}}{1+\gamma}\right\} \quad \text { subject to } \\
e_{i, t+k}=\min \left\{\left(\frac{u^{\prime}\left(c_{t+k}\right)}{\phi} \frac{w_{t}^{*}}{p_{t+k}}\right)^{\frac{1}{\gamma}}, \Psi_{t+k}\left(w_{t}^{*}\right)\right\},
\end{gathered}
$$

where $\Psi_{t+k}(\cdot)$ is the desired labor demand from the firm's side and $\Phi\left(w_{i, t}\right)$ is given by

$$
\Phi\left(w_{i, t}\right)=\left(\frac{u^{\prime}\left(c_{t+k}\right)}{\phi} \frac{w_{i, t}}{p_{t}}\right)^{\frac{1}{\gamma}}
$$

In the standard model, the constraint for the union is simply

$$
e_{i, t+k}=\Psi_{t+k}\left(w_{t}^{*}\right)
$$

Note that we have defined three objects: labor supply in variety $i$,

$$
\ell_{i, t}=\Phi_{t}\left(w_{i, t}\right)=\left(\frac{u^{\prime}\left(c_{t+k}\right) w_{i, t}}{\phi p_{t}}\right)^{\frac{1}{\gamma}}
$$

labor demand in variety $i$,

$$
n_{i, t}=\Psi_{t}\left(w_{i, t}\right)=\left[\frac{w_{i, t}}{(1-\alpha) z_{t} k_{t}^{\alpha} e_{t}^{-\alpha} p_{t}}\right]^{-\epsilon_{w}} e_{t}
$$

and actual labor in variety $i$,

$$
e_{i, t}=\min \left\{\ell_{i, t}, n_{i, t}\right\}
$$

To complete the model, we include a simple Taylor type monetary policy rule:

$$
\log R_{t}=\log \frac{1}{\beta}+\phi_{\pi} \pi_{t}+\phi_{y} \log \frac{y_{t}}{y^{*}}+\eta_{t}
$$


where $\pi_{t}=\log \frac{p_{t}}{p_{t-1}}$ and $y^{*}$ is the steady-state output level. The shock to the monetary policy rule follows an $\operatorname{AR}(1)$ process,

$$
\eta_{t}=\rho_{m} \eta_{t-1}+\zeta_{t}^{m}, \quad \zeta_{t}^{m} \sim \mathbb{N}\left(0, \sigma_{m}^{2}\right) .
$$

The details of the numerical solution via global methods of this economy can be found in Appendix D.

\subsection{The Approximated Drèze Equilibrium}

Even in the simplified staggered wage model, computing the exact Drèze equilibrium is computationally intense. We therefore consider an approximation to the Drèze equilibrium which does not require the global solution. It has a much smaller computational burden and can be applied to medium-size DSGE models. As in our calculation of the voluntary ex-post aggregate labor, we also employ the log-linearized solution of the demand-determined allocation and then impose the ex post labor supply constraint. But unlike in the construction of the ex-post labor, the approximated Drèze equilibrium reconstructs all the main aggregate variables recursively, including capital, output, interest rate, and so on, guaranteeing that the resources constraints are satisfied. In what follows, we compare this approximation with the exact Drèze equilibrium, and we find that the allocations are very similar. As a result, we argue that the approximated Drèze equilibrium can be used to address questions in medium-size DSGE models where computing the exact Drèze equilibrium is extremely hard. Specifically, the construction of the approximated Drèze equilibrium consists of the following four logical steps.

Step 1: Log-linearize and solve the demand-determined equilibrium This is a standard step. The decision rules are required, not just a simulation.

Step 2: Recursively construct a voluntary ex-post measure of labor This step is what we described in Section 3.1. The key difference is that there we use the sequence of capital stocks yielded by the demanddetermined equilibrium, which may not be feasible. Thus, at this stage we construct a measure of the voluntary labor one period at a time, denoted as $e_{t}^{a}$. In this step we keep track of historical wages, $w_{t}^{a}$, which also include the information about the cross-sectional wage distribution.

Step 3: Recursively construct the main aggregate variables Here we use the labor in period $t, e_{t}^{a}$, and the previous period series of capital $k_{t}^{a}$ to calculate output $y_{t}^{a}$ (which is also used to construct the output gap). We then use the same policy function as in the demand-determined equilibrium to determine the newly set wage and price level. This is an approximation, since in the true Drèze economy, agents will take into account the possibility that the labor supply constraint may be binding. The interest rate $R_{t}^{a}$ is set by using the reconstructed output gap. This part is mechanical.

Step 4: Determine consumption, investment, and next period capital This step is not mechanical. We have considered two possibilities: use the same consumption-to-output ratio or the same consumption 
of the demand-determined solution (investment is set residually to satisfy the resource constraint). We finally chose the same consumption because choosing the consumption-to-output ratio sometimes leads to countercyclical consumption. More specifically, in the demand-determined economy, after a positive technology shock, the consumption-output ratio is below its steady-state level because agents understand that it is better to increase investment to take advantage of the temporary high productivity. In the Drèze equilibrium, however, the response of labor is much more subdued with the same positive technology shock, which may lead to a much smaller expansion. If we used the low consumption-to-output ratio of the demand-determined allocation, there would be a recession rather than an expansion.

We do not want to argue that our approximation strategy is conceptually ideal, and we are aware that the allocation obtained in this approximation is subject to the fact that agents are not fully rational. The usefulness of this approximated equilibrium is simply justified by its small distance to the true Drèze equilibrium as we will show next.

\subsection{A Comparison between the Drèze Equilibrium and Its Approximation}

We now specify the staggered wage model quantitatively and solve for the Drèze equilibrium and for its approximation. The model has a large number of state variables to keep track of the wage distribution (see Appendix $\mathrm{D}$ for more details). The model period is a quarter and the annual interest rate in the steady state is $4 \%$. The implied Frisch elasticity is $0.75\left(\frac{1}{\gamma}\right)$, similar to estimates in Heathcote et al. (2010). The labor share is 0.64 , and the capital depreciation rate is 0.08 annually. The process for the TFP shock is similar to the one used in Ríos-Rull and Santaeulàlia-Llopis (2010). The monetary policy rule is the same as in Christiano et al. (2011). The persistence of the monetary shock is 0.5, the same as in Galí (2008). We set the standard deviation of the innovation to the monetary shock to be 0.004 . As discussed earlier, the most important parameter is $\epsilon_{w}$, which determines the wage markup. The one we use here implies a $10 \%$ wage markup. If we apply the logic of equation (12), our choice of $\epsilon_{w}$ and $\gamma$ leads to a $6 \%$ average unemployment rate ${ }^{15}$ (the parameterization is summarized in Table 4). We choose the duration of the wage contract to be four model periods, or one year.

Table 4: Baseline Parameters

\begin{tabular}{cccccccccccc}
\hline$\beta$ & $\sigma$ & $\gamma$ & $\phi_{\pi}$ & $\phi_{y}$ & $\alpha$ & $\delta$ & $\epsilon_{w}$ & $\rho_{z}$ & $\sigma_{z}$ & $\rho_{m}$ & $\sigma_{m}$ \\
\hline 0.99 & 1.0 & 1.5 & 1.5 & 0.0 & 0.36 & 0.02 & 11.0 & 0.95 & 0.006 & 0.50 & 0.004 \\
\hline
\end{tabular}

Figure 5 shows sample paths for the time series for labor for the four concepts that we are considering: the Drèze equilibrium, its approximation, voluntary ex-post labor and the demand-determined quantity of labor.

\footnotetext{
${ }^{15}$ Following Galí et al. (2012), the unemployment rate in sector $i$ (the economy-wide counterpart is immediate) is $u_{i, t}=$ $\log \ell_{i, t}-\log e_{i, t}$.
} 
We see here that for both shocks the Drèze equilibrium quantity of labor is similar to its approximation, and also to the voluntary ex-post quantity of labor and quite different than the demand-determined labor. A similar picture arises from Table 5 that reports the properties of labor in the simple economy using

Figure 5: Labor in the Staggered Wage Model with TFP and Monetary Shocks
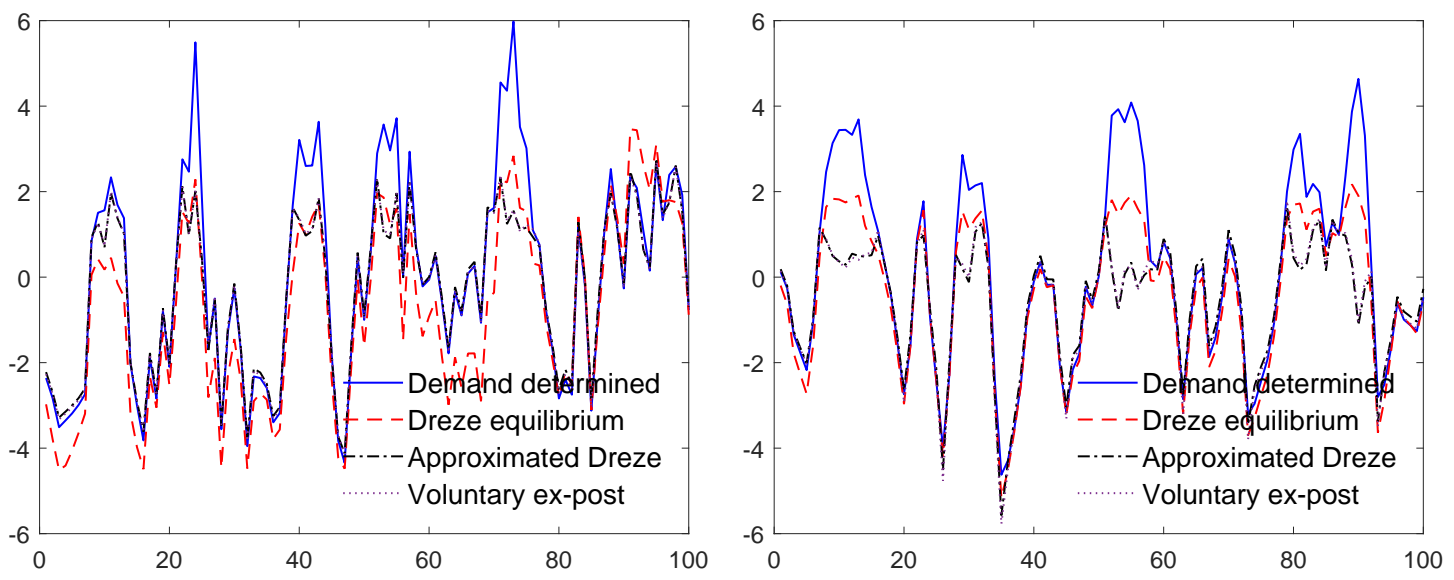

one shock at a time. The Drèze quantity of labor, that of its approximation, and the voluntary ex-post labor series share similar volatility and cyclicality. The demand-determined allocation, however, is much more volatile than the others. More than $10 \%$ of agents work against their will in the demand-determined economy. To some extent surprisingly, the correlation with the Drèze equilibrium quantity of labor in the case of the monetary shocks is highest in the demand-determined solution. ${ }^{16}$

Table 6 compares the business cycle properties of the main aggregate variables in the Drèze equilibrium, the approximated Drèze equilibrium, and the demand-determined economy (the voluntary ex-post solution only reconstructs the labor series, leaving other aggregate variables the same as the demand-determined solution). The volatility of variables in the Drèze equilibrium is similar to that in the approximated Drèze equilibrium and the demand-determined economy is much more volatile than the other two.

We conclude that the approximation to the Drèze equilibrium built via log-linearization of the demanddetermined solution and the recursive imposition of the minimum of the amount of labor supplied and demanded is a good approximation to a global solution of the Drèze equilibrium where the condition that labor is the minimum of the amount supplied and demanded is imposed ex-ante.

\footnotetext{
${ }^{16}$ This is due to the fact that with an expansionary monetary policy shock, the wage rate in the Drèze equilibrium is still set to accommodate the expansion, although to a lesser extent than the wage in the demand-determined solution. While the potential boom in the voluntary ex-post and the approximated Drèze equilibrium is often muted.
} 
Table 5: Properties of Labor in the Staggered Wage Model for Various Solutions

\begin{tabular}{|c|c|c|c|c|c|c|c|c|c|c|}
\hline & \multicolumn{5}{|c|}{ TFP shock } & \multicolumn{5}{|c|}{ Monetary Shock } \\
\hline & mean & var & $\begin{array}{l}\text { corr with } \\
\text { output }\end{array}$ & $\begin{array}{c}\text { corr with } \\
\text { Drèze }\end{array}$ & $\begin{array}{l}\% \text { labor } \\
\text { violation }\end{array}$ & mean & var & $\begin{array}{l}\text { corr with } \\
\text { output }\end{array}$ & $\begin{array}{c}\text { corr with } \\
\text { Drèze }\end{array}$ & $\begin{array}{l}\% \text { labor } \\
\text { violation }\end{array}$ \\
\hline Drèze Equil & -0.68 & 2.72 & 0.95 & 1.00 & - & -0.33 & 1.60 & 1.00 & 1.00 & - \\
\hline Approx Drèze Equil & -0.29 & 2.53 & 0.94 & 0.93 & - & -0.40 & 1.27 & 1.00 & 0.78 & - \\
\hline Voluntary ex-post & -0.32 & 2.60 & 0.89 & 0.93 & - & -0.44 & 1.36 & 0.78 & 0.77 & - \\
\hline Demand-Determined & - & 3.80 & 0.96 & 0.96 & 10.42 & - & 2.27 & 1.00 & 0.95 & 12.23 \\
\hline
\end{tabular}

Notes: All the variables except the mean are logged and HP filtered. The column \% labor violation corresponds to the average measure of workers whose labor supply constraint is violated.

Table 6: Business Cycle Statistics in the Staggered Wage Model with Various Solutions

\begin{tabular}{|c|c|c|c|c|c|c|}
\hline & \multicolumn{3}{|c|}{ TFP Shock } & \multicolumn{3}{|c|}{ Monetary Policy Shock } \\
\hline & $\begin{array}{l}\text { Drèze } \\
\text { Equilibrium }\end{array}$ & $\begin{array}{l}\text { Approximated } \\
\text { Drèze Equil. }\end{array}$ & $\begin{array}{c}\text { Demand } \\
\text { Determined }\end{array}$ & $\begin{array}{l}\text { Drèze } \\
\text { Equilibrium }\end{array}$ & $\begin{array}{l}\text { Approximated } \\
\text { Drèze Equil. }\end{array}$ & $\begin{array}{c}\text { Demand } \\
\text { Determined }\end{array}$ \\
\hline & \multicolumn{3}{|c|}{ Variance } & \multicolumn{3}{|c|}{ Variance } \\
\hline Output & 3.12 & 2.95 & 3.90 & 0.65 & 0.52 & 0.92 \\
\hline Labor & 2.67 & 2.53 & 3.79 & 1.60 & 1.29 & 2.26 \\
\hline Consumption & 0.17 & 0.17 & 0.19 & 0.01 & 0.01 & 0.02 \\
\hline \multirow[t]{2}{*}{ Investment } & 42.82 & 38.10 & 52.11 & 10.12 & 7.96 & 13.95 \\
\hline & \multicolumn{3}{|c|}{ Correlation with output } & \multicolumn{3}{|c|}{ Correlation with output } \\
\hline Labor & 1.00 & 1.00 & 1.00 & 1.00 & 1.00 & 1.00 \\
\hline Consumption & 0.61 & 0.57 & 0.62 & 0.61 & 0.57 & 0.62 \\
\hline Investment & 1.00 & 0.99 & 1.00 & 1.00 & 0.99 & 1.00 \\
\hline
\end{tabular}

Notes: All the variables are logged and HP filtered.

\section{An application of the Drèze Equilibrium: the Estimation of the Altig et al. (2011) Economy}

So far, we have argued that in New Keynesian models with wage settings à la Calvo, the use of demanddetermined labor yields allocations that are very different from those that the same parameterized model yields when labor is determined by the Drèze equilibrium where labor is the minimum of the amount supplied and the amount demanded. But this is not what really matters; perhaps different values of parameters yield similar properties between the two ways of determining the quantity of labor, and hence the answers that we obtain are the same. To settle this issue, we have to estimate the models under both types of labor determination. 
The estimation of Smets and Wouters (2007) uses modern Bayesian methods that rely on the linearity of the model. Although demand-determined models are not linear, they are very well approximated by loglinear approximations and hence are extremely well suited for Bayesian or maximum likelihood estimation. The combination of the linearity and the Gaussian shock structure permits a relatively easy mapping from model parameters to its implied likelihood. The key feature of the Drèze equilibrium is its nonlinear nature, which unfortunately prevents us from applying standard linear Kalman filter techniques in evaluating the model's likelihood. The alternative nonlinear Kalman filter requires large computational power, which is only feasible for models with a relatively small number of state variables.

We can, however, estimate the approximated Drèze equilibrium in Altig et al. (2011), the other central model in the New Keynesian literature. Altig et al. (2011) and its precedent Christiano et al. (2005) estimate a medium-scale DSGE model by matching the impulse responses of various variables to different shocks. The impulse responses are recovered from the estimation of a certain structural vector autoregression (VAR) model. The identification strategy in Altig et al. (2011) is similar to that in Christiano et al. (2005), where only nominal variables like the velocity of cash balances respond to contemporaneous monetary policy shocks but not the real variables such as hours, consumption, investment, and so on. It is also assumed that monetary policy is set conditional on the current values of real variables and only on the past values of nominal variables. In addition, innovations to technology (both neutral and capital embodied) are the only shocks that affect long-run labor productivity, and capital embodied technology shocks are the only shocks that affect the long-run relative price of investment goods. Crucial to this endeavour is the ability to identify the shocks, something that can be done with the three shocks in Altig et al. (2011).

The parameters of the model are chosen in such a way that the model's impulse responses to the structural shocks match their counterpart estimated from the data. In particular, three structural shocks are considered: a monetary shock, a neutral technology shock, and an embodied investment technology shock. The estimation method is generalized method of moments (GMM), which only requires the impulse response of the model. ${ }^{17}$ Because the likelihood of the model is not required, we can apply this estimation method to the approximated Drèze equilibrium using the same exogenously calibrated parameters than Altig et al. (2011).

Table 7 shows the properties of the estimates of the approximated Drèze equilibrium and of the demanddetermined allocation in the Altig et al. (2011) model with a 5\% markup. Our interpretation of these very different sets of estimates is that the unwillingness of households in the Drèze equilibrium to work a lot under some circumstances requires that other pieces of the model have to do a lot more work to create the observed fluctuations:

\footnotetext{
${ }^{17}$ The weighting matrix of GMM is diagonal with the inverse of the standard deviations of the impulse responses estimated in the structural VAR.
} 
Table 7: Estimated Parameter Values with 5\% Wage Markup Using 1 St.d Impulse Response Functions

\begin{tabular}{|c|c|c|}
\hline & Demand-Determined & Approximated Drèze \\
\hline Std Dev of neutral technology shock, $\sigma_{\mu z}$ & $\begin{array}{c}0.068 \\
(0.046)\end{array}$ & $\begin{array}{c}0.140 \\
(0.089)\end{array}$ \\
\hline Autocor neutral technology shock, $\rho_{\mu_{z}}$ & $\begin{array}{c}0.902 \\
(0.102)\end{array}$ & $\begin{array}{c}0.697 \\
(0.240)\end{array}$ \\
\hline Std Dev of monetary shock, $\sigma_{M}$ & $\begin{array}{l}0.331 \\
(0.084)\end{array}$ & $\begin{array}{l}0.325 \\
(0.078)\end{array}$ \\
\hline Autocor monetary policy shock, $\rho_{M}$ & $\begin{array}{l}-0.037 \\
(0.111)\end{array}$ & $\begin{array}{l}-0.040 \\
(0.130)\end{array}$ \\
\hline Std Dev of embodied technology shock, $\sigma_{\mu} \Upsilon$ & $\begin{array}{l}0.303 \\
(0.042)\end{array}$ & $\begin{array}{l}0.286 \\
(0.046)\end{array}$ \\
\hline Autocor embodied technology shock, $\rho_{\mu_{\Upsilon}}$ & $\begin{array}{c}0.241 \\
(0.224)\end{array}$ & $\begin{array}{c}0.318 \\
(0.176)\end{array}$ \\
\hline Wage rigidity, $\xi_{w}$ & $\begin{array}{c}0.722 \\
(0.123)\end{array}$ & $\begin{array}{c}0.825 \\
(0.043)\end{array}$ \\
\hline Price rigidity, $\gamma$ & $\begin{array}{c}0.040 \\
(0.029)\end{array}$ & $\begin{array}{c}0.054 \\
(0.039)\end{array}$ \\
\hline Variable capital utilization, $\sigma_{a}$ & $\begin{array}{l}1.995 \\
(2.222)\end{array}$ & $\begin{array}{l}4.564 \\
(7.070)\end{array}$ \\
\hline Investment adjustment cost, $S^{\prime \prime}$ & $\begin{array}{l}3.281 \\
(2.038)\end{array}$ & $\begin{array}{l}4.752 \\
(2.378)\end{array}$ \\
\hline Interest semi-elasticity of money demand, $\epsilon$ & $\begin{array}{l}0.808 \\
(0.208)\end{array}$ & $\begin{array}{l}0.779 \\
(0.193)\end{array}$ \\
\hline Habit formation, $b$ & $\begin{array}{c}0.706 \\
(0.045)\end{array}$ & $\begin{array}{c}0.698 \\
(0.058)\end{array}$ \\
\hline Effects of neutral technology shock on policy, $\rho_{x z}$ & $\begin{array}{c}0.343 \\
(0.266)\end{array}$ & $\begin{array}{c}0.195 \\
(0.480)\end{array}$ \\
\hline Effects of embodied technology shock on policy, $\rho_{x} \Upsilon$ & $\begin{array}{l}0.824 \\
(0.154)\end{array}$ & $\begin{array}{l}0.832 \\
(0.132)\end{array}$ \\
\hline Scaling factor of neutral technology shock, $c_{z}$ & $\begin{array}{l}2.997 \\
(2.310)\end{array}$ & $\begin{array}{l}1.027 \\
(0.749)\end{array}$ \\
\hline Scaling factor of neutral technology shock, $c_{z}^{p}$ & $\begin{array}{l}1.327 \\
(1.381)\end{array}$ & $\begin{array}{l}0.665 \\
(0.650)\end{array}$ \\
\hline Scaling factor of embodied technology shock, $c_{\Upsilon}^{p}$ & $\begin{array}{c}0.135 \\
(0.244)\end{array}$ & $\begin{array}{l}0.107 \\
(0.268)\end{array}$ \\
\hline Scaling factor of embodied technology shock, $c_{\gamma}$ & $\begin{array}{l}0.246 \\
(0.244)\end{array}$ & $\begin{array}{l}0.305 \\
(0.266)\end{array}$ \\
\hline
\end{tabular}


1. The neutral technology shock is dramatically affected. To induce more movement in labor, the estimated shock is now both much more volatile and less persistent: the unconditional variance of the neutral technology shock is 0.039 in the Drèze equilibrium relative to 0.024 in the demanddetermined allocation. A larger, but less persistent, shock makes households more willing to supply labor.

2. The rigidity of wages and prices is somewhat larger. The lower response of labor in the Drèze equilibrium also requires, perhaps a bit counterintuitively, larger rigidities in the model to generate more fluctuations. This is true both for wages, where the Drèze equilibrium is imposed, and for prices, where it is not.

3. Two other pieces of the model are now larger. The role of variable capital utilization is now value, as is investment adjustment cost parameter. Still, these two parameters are somewhat imprecisely estimated and we should not insist on them.

Table 8 shows what the different solutions yield for each of set of estimates obtained. The left panel of the table shows the effects of the processes estimated via the demand-determined solution for labor when we look both at the demand-determined solution and at the approximated Drèze equilibrium. The right panel shows the effects of the processes estimated with the approximated Drèze equilibrium when we both look at the demand-determined solution and at the approximated Drèze equilibrium. The numbers in boldface are the properties of the economies when they are used to estimate the parameters. The Table shows some other important features of the differences between the demand-determined solution and the approximated Drèze equilibrium:

4. The estimates of the approximated Drèze equilibrium increase the role of the neutral technology shock. The variance of labor is larger using both equilibrium notions relative to the demanddetermined estimates. Comparing the original Altig et al. (2011) results with the Drèze equilibrium under the new estimates, the contribution of the neutral technology shock to the variance of labor increases from $13 \%$ to $71 \%$, that of the investment or embodied technology shock shrinks from $49 \%$ to $16 \%$, and that of the monetary shocks also shrinks from $33 \%$ to $15 \%{ }^{18}$

5. Under both sets of estimates, the variance of labor is much larger in the approximated Drèze equilibrium. The unwillingness of households to work under many circumstances generates recessions that are not present in the demand-determined solution.

\footnotetext{
${ }^{18}$ As the quick-witted reader may have noticed, the contributions of the orthogonal shocks to the variance of labor add up to slightly above $100 \%$. The reason for this is the nonlinear nature of the model. Fortunately for our analysis, the differences are quite small, and the contribution of each individual shock when the others are shut out gives a good picture of their overall contribution.
} 
Table 8: Effects on Labor of Shocks for Alternative Estimation Strategies

\begin{tabular}{|c|c|c|c|c|c|c|c|c|}
\hline & \multicolumn{4}{|c|}{$\begin{array}{l}\text { Estimated with } \\
\text { Demand-Determined }\end{array}$} & \multicolumn{4}{|c|}{$\begin{array}{c}\text { Estimated with } \\
\text { Approximated Drèze: } 1 \text { std shock }\end{array}$} \\
\hline & mean & var & $\begin{array}{c}\text { corr with } \\
\text { output }\end{array}$ & $\begin{array}{l}\% \text { labor } \\
\text { violation }\end{array}$ & mean & var & $\begin{array}{l}\text { corr with } \\
\text { output }\end{array}$ & $\begin{array}{l}\% \text { labor } \\
\text { violation }\end{array}$ \\
\hline & \multicolumn{8}{|c|}{ Neutral Technology Shock } \\
\hline Demand-Determined & - & 0.18 & 0.87 & 15.09 & - & 0.24 & 0.97 & 19.03 \\
\hline \multirow[t]{2}{*}{ Approximated Drèze } & -1.57 & 1.16 & 0.96 & - & -2.59 & 1.41 & 0.95 & - \\
\hline & \multicolumn{8}{|c|}{ Investment Technology Shock } \\
\hline Demand-Determined & - & 0.67 & 0.99 & 6.22 & - & 0.52 & 0.99 & 7.89 \\
\hline \multirow[t]{2}{*}{ Approximated Drèze } & -0.42 & 0.34 & 0.98 & - & -0.55 & 0.32 & 0.99 & - \\
\hline & \multicolumn{8}{|c|}{ Monetary Shock } \\
\hline Demand-Determined & - & 0.46 & 1.00 & 2.56 & - & 0.33 & 1.00 & 1.15 \\
\hline \multirow[t]{2}{*}{ Approximated Drèze } & -0.07 & 0.33 & 0.99 & - & -0.01 & 0.30 & 1.00 & - \\
\hline & \multicolumn{8}{|c|}{ All Shocks } \\
\hline Demand-Determined & - & 1.38 & 0.96 & 18.83 & - & 1.15 & 0.95 & 22.63 \\
\hline Approximated Drèze & -2.28 & 2.06 & 0.98 & - & -3.41 & 1.99 & 0.96 & - \\
\hline
\end{tabular}

Notes: Numbers are in percentages except for the correlation with output.

There are two main takeaways from this exercise. First, addressing the violation of the labor supply constraint does not have innocuous consequences for the model. The estimates under the Drèze equilibrium are significantly different than those obtained under the demand-determined solution. Second, the particular approach we used to address the issue, the Drèze equilibrium, does not improve the empirical performance of DSGE models with sticky wages. To induce workers to increase their labor supply, the required persistence for TFP process is much lower and the required innovation is much more volatile that what most economists think is the case. Also, the fraction of fluctuations that are accounted by TFP shocks becomes much higher. The model with Drèze equilibrium brings the results further away from the more reduced-form evidence. Even though the Drèze equilibrium is the natural candidate in sticky wage models to avoid the violation of the labor supply constraint in models with Calvo wage setting, perhaps other alternatives should be explored to achieve the goal that it can simultaneously respect agents' willingness to work and fit the aggregate time series. Such alternatives are likely going to depart from the strict Calvo environment.

Robustness of findings The estimation method of Altig et al. (2011) is to minimize the distance between the impulse response of an structural VAR in the data and the theoretical VAR of the model, a procedure that works cleanly with a model that is linear (or where its log-linear approximation is deemed to be accurate enough). However, the Drèze equilibrium is very non linear which raises two concerns. First, 
the impulse response function depends on the size of the size shock that is used to evaluate it. Figure 6 illustrates this point. The impulse responses of labor to a neutral technology shock are plotted for the data, and for the demand-determined solution and the Drèze equilibrium approximation for a $10 \%$ markup for different size shocks (1, 2.5 and 3 times the standard deviation). We see how both the data and the demand-determined solution scale nicely as the shock gets larger, but not the Drèze equilibrium where the expansion turns into a recession within a couple of years. The second concern arises as a result of the first one and can also be seen in the picture: the demand-determined and the Drèze impulse response are equal for small values of the shocks and different for large values of the shock. This is likely to be generally the case, as for small values of the shock the labor supply constraint is unlikely to be binding. Consequently, impulse response functions of the Drèze equilibrium to small shocks hide the violations of the labor supply constraint.

Figure 6: IRF of Labor to Neutral Tech. Shock: Estimation with Demand-Determined Model, 10\% Markup
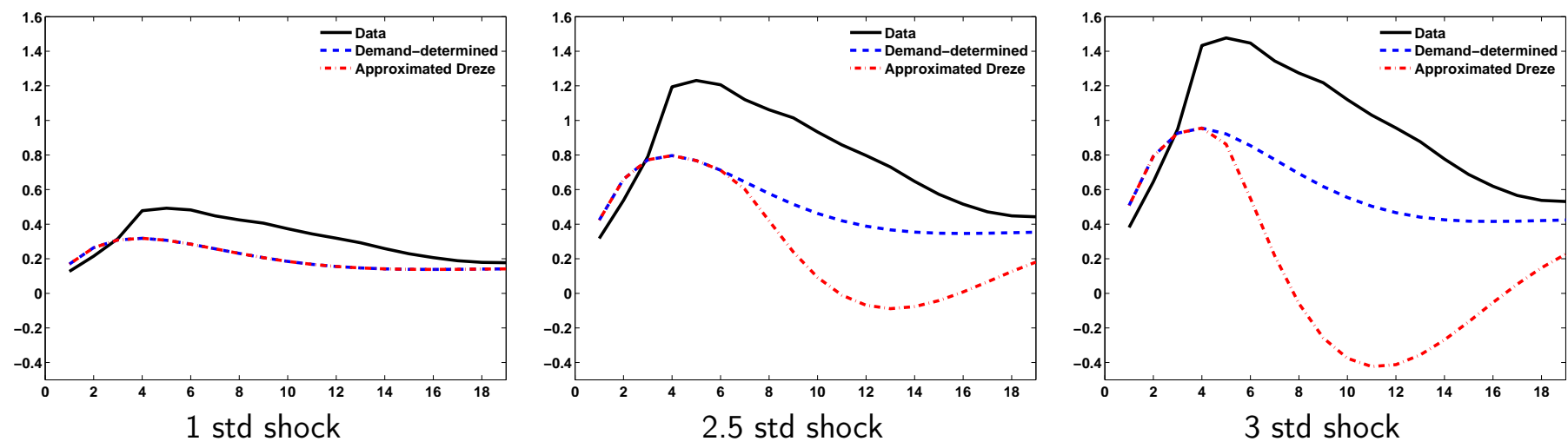

To deal with this issue, we have reestimated the Drèze equilibrium with the impulse response of a shock of size 1.5 standard deviations and we report them in Appendix A. The findings that we have reported are replicated in this case, if anything the estimate of the autocorrelation of neutral productivity shocks becomes even smaller than before. We also report Appendix $A$ the estimates that we obtain for $10 \%$ and for $15 \%$ markups obtained targeting the impulse response to various sizes of the shocks (larger than one standard deviation for the reasons adduced before). The findings are again confirmed, the neutral technical shock is much more important than in the demand determined economy, with the differences shrinking as we look at economies with a larger markup. We conclude the exploration of this issue by estimating both the demand-determined and the Drèze economies for larger markups using impulse responses to larger shocks. Again the same features reappear, the role of neutral technical change increases albeit with a much larger variance in the Drèze equilibrium relative to the demand-determined solution. We conclude that using larger markups and larger shocks to specify which impulse responses the model attempts to replicate generates patterns similar to those in our baseline specification of the Altig et al. (2011) model. 


\section{Wage Adjustment Costs à la Rotemberg}

A popular alternative to nominal wage rigidity à la Calvo is the wage-adjustment cost mechanism proposed by Rotemberg (1982), where the nominal wage can be reset every period, but there is a quadratic adjustment cost when its value is changed. As shown in Born and Pfeifer (2016), by suitably choosing the adjustment quadratic cost parameter, the aggregate wage dynamics in the Rotemberg model and the Calvo model are identical up to a first order approximation. But being observationally equivalent at the aggregate level does not imply that the cross-sectional labor allocation and the extent to which the labor supply constraint is violated is the same: in the Calvo model, the aggregate wage is less volatile than the wages for each labor variety, while in the Rotemberg model, a common wage prevails in the economy and is reset every period. In the Calvo model there are workers whose wage was set at a low level long time ago and hence they are likely to have their labor supply constraint violated making it natural to expect that the labor supply constraint will be binding more frequently than in the Rottemberg model.

Meanwhile, as mentioned in the introduction, the Calvo pricing assumption may be too rigid and one may want to specify additional circumstances under which prices or wages could change (violation of the labor supply constraint being one of them). The Rotemberg model could be viewed as an example where wage rigidity is introduced without the strong assumption that wages cannot be changed no matter what. As a result, it is not subject to the Barro (1977) critique.

To explore the extent to which violating the labor supply constraint is quantitatively relevant in the Rotemberg model, we revisit the Smets and Wouters (2007) and Altig et al. (2011) models under a Rottemberg wage adjustment mechanism and we compare its performance relative to the restriction that the amount of labor cannot exceed what workers are willing to work.

Consider economies like the ones described in the previous sections except in the fact that labor unions can change the wage every period subject to a quadratic wage adjustment cost. The variety $i$ union's problem differs from that in Section 2 and becomes

$$
\begin{aligned}
& \max _{\left\{w_{i, t+k}\right\}} \mathbb{E}_{t}\left\{\sum_{k=0}^{\infty} \beta^{k}\left[u^{\prime}\left(c_{t+k}\right)\left(\frac{w_{i, t+k}}{p_{t+k}} n_{i, t+k}-\frac{\vartheta}{2}\left(\frac{w_{i, t+k}}{w_{i, t+k-1}}-1\right)^{2} y_{t+k}\right)-v\left(n_{i, t+k}\right)\right]\right\}, \\
& \text { subject to } \quad n_{i, t+k}=\left(\frac{w_{i, t+k}}{w_{t+k}}\right)^{-\epsilon_{w}} n_{t+k},
\end{aligned}
$$

where parameter $\vartheta$ determines the size of the wage adjustment cost which is assumed to be proportional to nominal output $p_{t} y_{t}$. Here, the union implicitly assumes that workers are always willing to supply amount $n_{i, t+k}$ of labor. Due to the equivalence of the Rotemberg model and the Calvo model after linearization, we choose a Rotemberg cost parameter $\vartheta$ so that it will imply the same wage Phillips curve as that in the Calvo model. 
To see whether the standard characterization of Rottemberg pricing (the demand-determined solution) violates the requirement that agents do not work more than what they want we compare the demanddetermined quantity of labor that solved the previous problem, $n_{t}^{*}$, with the minimum of this demanddetermined quantity and the actual amount of work that agents are willing to supply, this is, the $\ell_{t}^{*}$ that solves

$$
\frac{w_{t}}{p_{t}}=\frac{v^{\prime}\left(\ell_{t}\right)}{u^{\prime}\left(c_{t}\right)}
$$

We denote this $\min \left\{n_{t}^{*}, \ell_{t}^{*}\right\}$ the ex-post labor. Note that in this case we do not need to construct the cross-sectional labor demand and labor supply as we did in Section 3.1 for the Calvo type economies since all labor types have the same wage in equilibrium.

Table 9: Altig et al. (2011) with Rotemberg Adjustment Costs

\begin{tabular}{|c|c|c|c|c|c|c|c|c|}
\hline & \multicolumn{4}{|c|}{$5 \%$ wage markup } & \multicolumn{4}{|c|}{$10 \%$ wage markup } \\
\hline & mean & var & $\begin{array}{c}\text { corr with } \\
\text { output }\end{array}$ & $\begin{array}{l}\% \text { labor } \\
\text { violation }\end{array}$ & mean & var & $\begin{array}{c}\text { corr with } \\
\text { output }\end{array}$ & $\begin{array}{l}\% \text { labor } \\
\text { violation }\end{array}$ \\
\hline Demand-Determined & - & 1.38 & 0.96 & 5.37 & - & 1.35 & 0.96 & 0.06 \\
\hline Voluntary Ex-post & -0.07 & 1.24 & 0.93 & - & 0.00 & 1.35 & 0.96 & - \\
\hline
\end{tabular}

Notes: All the variables except the mean are logged and HP filtered. The column $\%$ labor violation corresponds to the frequency of the labor supply constraint violation. The wage markup used is $5 \%$.

Tables 9 and 10 compare the properties of the quantities of labor allocations implied by ignoring workers willingness to work with those that arise when such constrained is taking into account. The labor supply constraint is still sometimes violated with Rottemberg adjustment costs, although as expected, less often than in economies with Calvo pricing. In the Altig et al. (2011) economy, the labor supply constraint binds $5 \%$ of the time, and labor volatility is $11 \%$ larger when ignoring the labor supply constraint than when imposing it with a $5 \%$ markup, while it is essentially identical with a $10 \%$ markup.

In the Smets and Wouters (2007) without wage markup shocks, and with a 5\% markup the labor supply constraint binds $19 \%$ of the time and has $23 \%$ larger labor volatility when we ignore the labor supply constraint. There are almost no differences with a larger markup. When the wage markup shocks are also included, the differences between the economy that ignores the labor supply constraint and that where we prevent that constraint to be violated are much more dramatic. For a 5\% markup the constraint is violated $36 \%$ of the time, leading to a labor volatility $16 \%$ larger and a correlation with output also much larger in the unconstrained economy. With a $15 \%$ markup the constraint binds $16 \%$ of the time, volatility is still $5 \%$ larger and labor is clearly more correlated with output. Even with a the $25 \%$ markup the differences are noticeable: hours are 3\% more volatile and the correlation is .04 larger than in the constrained economy. 
Table 10: Smets and Wouters (2007) with Rotemberg Adjustment Costs

\begin{tabular}{|c|c|c|c|c|c|c|c|c|}
\hline & \multicolumn{4}{|c|}{ w/o wage markup shock } & \multicolumn{4}{|c|}{ with wage markup shock } \\
\hline & mean & var & $\begin{array}{l}\text { corr with } \\
\text { output }\end{array}$ & $\begin{array}{l}\% \text { labor } \\
\text { violation }\end{array}$ & mean & var & $\begin{array}{c}\text { corr with } \\
\text { output }\end{array}$ & $\begin{array}{l}\% \text { labor } \\
\text { violation }\end{array}$ \\
\hline \multicolumn{9}{|c|}{$5 \%$ wage markup } \\
\hline Demand-Determined & - & 1.01 & 0.80 & 18.48 & - & 1.16 & 0.82 & 35.79 \\
\hline Voluntary Ex-post & -0.19 & 0.82 & 0.69 & - & -1.12 & 1.00 & 0.49 & - \\
\hline \multicolumn{9}{|c|}{$15 \%$ wage markup } \\
\hline Demand-Determined & - & 0.95 & 0.79 & 0.19 & - & 1.13 & 0.81 & 15.55 \\
\hline Voluntary Ex-post & 0.00 & 0.95 & 0.79 & - & -0.41 & 1.07 & 0.68 & - \\
\hline \multicolumn{9}{|c|}{$25 \%$ wage markup } \\
\hline Demand-Determined & - & 0.93 & 0.78 & 0.00 & - & 1.12 & 0.81 & 5.50 \\
\hline Voluntary Ex-post & 0.00 & 0.93 & 0.78 & - & -0.12 & 1.09 & 0.77 & - \\
\hline
\end{tabular}

Notes: All the variables except the mean are logged and HP filtered. The column \% labor violation corresponds to the frequency of the labor supply constraint violation.

To summarize, with a Rotemberg wage setting mechanism the issue of agents working against their will is also present. In the Altig et al. (2011) economy this happens only when the markup is no higher than $5 \%$. In the Smets and Wouters (2007) economy this happens also with markups no higher than 5\% when we ignore wage markup shocks. But when we include them, the labor supply constraint becomes very relevant as ignoring it yields noticeably larger labor volatility and correlation between labor and output than when it is imposed.

However, like in the Calvo economies, the ex-post imposition of the labor supply constraint does not give us a complete picture of what is the behavior of the economy when the quantity of labor violates the labor supply constraint. We should explicitly incorporate the constraint as part of the equilibrium. Because the unions reset prices each period, the imposition of the labor supply in the wage setting problem is more straightforward and the explicit implementation of the equilibrium as a Drèze equilibrium is no longer necessary. In particular, we add the following constraint to the problem described in (36)

$$
n_{i t} \leq \ell_{i t}, \quad \text { where } \ell_{i t} \text { solves } \quad \frac{w_{i t}}{p_{t}}=\frac{v^{\prime}\left(\ell_{i t}\right)}{u^{\prime}\left(c_{t}\right)}
$$

Note that the unions' problem is one with occasionally binding constraints where the actual constraint limit is a varying one which precludes the use of linear methods. We cannot compute the original Altig 
et al. (2011) or Smets and Wouters (2007) models with the occasionally binding constraint, but we are able to solve a simpler economy explicitly with unions that internalize the labor supply with the use of global methods. This simple economy is similar to the one considered in Section 4.1. The differences are: (1) we replace the Taylor staggered wage contract with the Rotemberg wage setting; (2) the firms are not subject to the quantity constraint (22). We set $\vartheta$ such that the implied Calvo parameter $\theta_{w}=0.75$. For this simple economy, we can also define an approximate solution exactly like we did in Section 4.3 and see how it compares with the exact solution and with the solution with an ex-post implementation of the labor supply constraint (for comparison we also look at the allocation that ignores the constraint).

Table 11: Properties of Labor in the Rotemberg Model for Various Solutions

\begin{tabular}{lccccccccc}
\hline \hline & mean & var & $\begin{array}{c}\text { corr with } \\
\text { output }\end{array}$ & $\begin{array}{c}\text { \% labor } \\
\text { violation }\end{array}$ & mean & var & $\begin{array}{c}\text { corr with } \\
\text { output }\end{array}$ & $\begin{array}{c}\text { \% labor } \\
\text { violation }\end{array}$ \\
\hline Ex-ante Labor Constrained & -0.39 & 3.95 & 0.99 & - & -0.76 & 2.63 & 1.00 & - \\
Approximated Ex-ante & -0.11 & 3.93 & 0.99 & - & -0.28 & 2.78 & 1.00 & - \\
Voluntary Ex-post & -0.14 & 3.92 & 0.97 & - & -0.38 & 2.79 & 0.91 & - \\
Demand-Determined & - & 4.31 & 0.99 & 6.78 & - & 3.42 & 1.00 & 12.06 \\
\hline
\end{tabular}

Notes: All the variables except the mean are logged and HP filtered. The column \% labor violation corresponds to the frequency of the labor supply constraint violation.

Table 11 reports the properties of the various labor allocations. We see that the ex-ante labor constraint is very similar to the approximated ex-ante and also to the economy with the ex-post constraint (slightly less so for the monetary policy shock) and they are all very different than the economy that ignores the labor constraint. We conclude that the use of the ex-post labor allocation for the Altig et al. (2011) and the Smets and Wouters (2007) economies gives as a reasonable picture of how the equilibrium that takes into account the labor supply constraint would look.

\section{Conclusion}

In this paper, we have explored what happens in the canonical New Keynesian models when the demanddetermined solution for labor is replaced by a solution that ensures that the quantity of labor used in the economy is not larger than the quantity of labor that agents are willing to supply. In economies with wage setting à la Calvo this is accomplished by using the Drèze equilibrium (or an approximation to it), while in economies with wage adjustment costs à la Rotemberg this is accomplished by imposing the non-violation of the labor supply constraint (or an approximation to it) to the wage setting unions.

We have argued that the differences are large. Typically, between $5 \%$ and $25 \%$ of the labor force is working against agents' will during any given period in a demand-determined solution. Comparing the demand- 
determined solution with equilibrium allocations that satisfy the labor supply constraint in standard models, we see substantially different labor volatilities, usually (but not always) larger in the demand-determined models. The problem is somewhat less dramatic in Rotemberg style settings but still yields quite different properties even for large wage markups when wage markup shocks are taken into account. This feature makes us suspect that the problem is even more dramatic than what we show here. Recall that in the Calvo implementation of the Smets and Wouters (2007) economy we did not pose wage markup shocks for the technical reasons described above. What the Rotemberg economy, where wage markup shocks can be taken into account, tells us is that these shocks make the labor supply constraint have a much larger role. So if these shocks where to be implementable in the presence of a labor supply constraint in the Calvo economy, it would be very likely that this constraint would be violated much more often than what we report.

More importantly, perhaps, when we estimate the Drèze equilibrium in the economies with wage setting à la Calvo, it yields answers that are substantially different from those provided by the demand-determined solution estimates: in the context of the Christiano et al. (2005) and Altig et al. (2011) economy, the role of neutral technology shocks rises from $13 \%$ to $70 \%$, these shocks become larger and less persistent, and the estimates of the rigidities become larger.

These findings are dependent on the particular wage mark of the economy. With wage mark-ups sufficiently large, the problem becomes almost (but not completely) nonexistent. Still our calculations are made for what we think are the most empirically values of the mark-up/

We conclude by encouraging researchers to be more concerned about the problem that wage rigidity causes in worker's willingness to work, and to either incorporate it the labor supply constraint explicitly in their models or to consider models of wage rigidity less prone to this problem, perhaps a version of the Calvo model where wages could also be changed when the labor supply constraint binds. 


\section{References}

Alessandria, G., Kaboski, J. P., and Midrigan, V. (2010). Inventories, Lumpy Trade, and Large Devaluations. American Economic Review, 100(5):2304-39.

Altig, D., Christiano, L. J., Eichenbaum, M., and Linde, J. (2011). Firm-specific capital, nominal rigidities and the business cycle. Review of Economic Dynamics, 14(2):225-247.

Barro, R. J. (1977). Long-term contracting, sticky prices, and monetary policy. Journal of Monetary Economics, 3(3):305-316.

Barro, R. J. and Grossman, H. I. (1971). A general disequilibrium model of income and employment. American Economic Review, 61(1):82-93.

Bénassy, J.-P. (1993). Nonclearing markets: microeconomic concepts and macroeconomic applications. Journal of Economic Literature, 31(2):732-761.

Bills, M. (2004). Studying price markups from stockout behavior. Manuscript, University of Rochester, http://www.econ.rochester.edu/people/BilsPapers/st1.pdf.

Born, B. and Pfeifer, J. (2016). The New Keynesian wage Phillips curve: Calvo vs. Rotemberg. Working Paper.

Chari, V. V., Kehoe, P. J., and McGrattan, E. R. (2002). Can sticky price models generate volatile and persistent real exchange rates? Review of Economic Studies, 69(3):533-563.

Chari, V. V., Kehoe, P. J., and McGrattan, E. R. (2009). New keynesian models: Not yet useful for policy analysis. American Economic Journal: Macroeconomics, 1(1):242-266.

Christiano, L., Eichenbaum, M., and Rebelo, S. (2011). When is the government spending multiplier large? Journal of Political Economy, 119(1):78-121.

Christiano, L. J., Eichenbaum, M., and Evans, C. L. (2005). Nominal rigidities and the dynamic effects of a shock to monetary policy. Journal of Political Economy, 113(1):1-45.

Christiano, L. J., Eichenbaum, M. S., and Trabandt, M. (2013). Unemployment and business cycles. Mimeo, Northwestern University.

Citanna, A., Crès, H., Drèze, J., Herings, P. J.-J., and Villanacci, A. (2001). Continua of underemployment equilibria reflecting coordination failures, also at walrasian prices. Journal of Mathematical Economics, 36(3):169-200.

Corsetti, G. and Pesenti, P. (2005). International dimensions of optimal monetary policy. Journal of Monetary Economics, 52(2):281-305. 
Dehez, P. and Drèze, J. H. (1984). On supply-constrained equilibria. Journal of Economic Theory, 33(1):172-182.

Drèze, J. H. (1975). Existence of an exchange equilibrium under price rigidities. International Economic Review, 16(2):301-320.

Drèze, J. H. (1997). Walras keynes equilibria coordination and macroeconomics. European Economic Review, 41(9):1735-1762.

Erceg, C. J., Henderson, D. W., and Levin, A. T. (2000). Optimal Monetary Policy with Staggered Wage and Price Contracts. Journal of Monetary Economics, 46(2):281-313.

Galí, J. (2008). Monetary Policy, Inflation, and the Business Cycle: An Introduction to the New Keynesian Framework. Princeton University Press.

Galí, J. (2011). The return of the wage Phillips curve. Journal of the European Economic Association, 9(3):436-461.

Galí, J., Smets, F., and Wouters, R. (2012). Unemployment in an Estimated New Keynesian Model. NBER Macroeconomics Annual, 26(1):329-360.

Gertler, M., Sala, L., and Trigari, A. (2008). An Estimated Monetary DSGE Model with Unemployment and Staggered Nominal Wage Bargaining. Journal of Money, Credit and Banking, 40(8):1713-1764.

Gertler, M. and Trigari, A. (2009). Unemployment fluctuations with staggered nash wage bargaining. Journal of Political Economy, 117(1):38-86.

Guerrieri, L. and lacoviello, M. (2015). Occbin: A toolkit to solve models with occasionally binding constraints easily. Journal of Monetary Economics, 70:22-38.

Hall, R. (2005). Employment fluctuations with equilibrium wage stickiness. American Economic Review, 95(1):50-65.

Hall, R. E. and Milgrom, P. R. (2008). The Limited Influence of Unemployment on the Wage Bargain. American Economic Review, 98(4):1653-1674.

Heathcote, J., Storesletten, K., and Violante, G. L. (2010). The macroeconomic implications of rising wage inequality in the united states. Journal of Political Economy, 118(4):681-722.

Herings, P. J.-J. (1996). Equilibrium existence results for economies with price rigidities. In Static and Dynamic Aspects of General Disequilibrium Theory, pages 121-186. Springer.

Herings, P. J.-J. (2014). General equilibrium and the new neoclassical synthesis. Economic Theory, 57(3):437-477. 
Kurz, M. (1982). Unemployment equilibrium in an economy with linked prices. Journal of Economic Theory, 26(1):100-123.

Levin, A. T., Onatski, A., Williams, J., and Williams, N. M. (2006). Monetary policy under uncertainty in micro-founded macroeconometric models. In Gertler, M. and Rogoff, K., editors, NBER Macroeconomics Annual 2005, volume 20, pages 229-312. MIT Press.

Lewis, H. G. (1986). Union relative wage effects. In Ashenfelter, O. and Layard, R., editors, Handbook of Labor Economics, volume 2, chapter 20, pages 1139-1181. North-Holland.

Malinvaud, E. (1977). The Theory of Unemployment Reconsidered. Yrjö Jahnsson Lectures. Wiley.

Michaillat, P. and Saez, E. (2015). Aggregate demand, idle time, and unemployment. The Quarterly Journal of Economics, 130(2):507-569.

Ríos-Rull, J.-V. and Santaeulàlia-Llopis, R. (2010). Redistributive shocks and productivity shocks. Journal of Monetary Economics, 57(8):931-948.

Rotemberg, J. J. (1982). Sticky prices in the United States. Journal of Political Economy, 90(6):11871211.

Smets, F. and Wouters, R. (2007). Shocks and frictions in us business cycles: a Bayesian DSGE approach. American Economic Review, 97(3):586-606.

Trujillo, J. (1985). Rational responses and rational conjectures. Journal of Economic Theory, 36(2):289301.

Van der Laan, G. (1980). Equilibrium under rigid prices with compensation for the consumers. International Economic Review, pages 63-73. 


\section{Appendix}

\section{A Details of the Estimation of Altig et al. (2011)}

The system of the log-linearized equations for estimation and simulation is the following:

$$
\begin{aligned}
& \mathbb{E}\left[\lambda_{z^{*}, t+1}-\frac{1}{1-\alpha} \mu \Upsilon_{t+1}-\mu_{z t+1}+\frac{\rho \rho_{t+1}+(1-\delta) \mu_{t+1}}{1-\delta+\rho} \mid \Omega_{t}^{p}\right]=0 \\
& \mathbb{E}\left\{S^{\prime \prime}\left(\mu \curlyvee \mu_{z^{*}}\right)^{2}\left[i_{t}-i_{t-1}+\mu_{\Upsilon t}+\frac{\alpha}{1-\alpha} \mu_{\Upsilon t}+\mu_{z t}\right]-\right. \\
& \left.\beta S^{\prime \prime}\left(\mu \curlyvee \mu_{z^{*}}\right)^{2}\left[i_{t+1}-i_{t}+\mu_{\Upsilon t+1}+\frac{\alpha}{1-\alpha} \mu_{\curlyvee t+1}+\mu_{z t+1}\right]-\mu_{t} \mid \Omega_{t}^{p}\right\}=0 \\
& \frac{\nu R}{\nu R+1-\nu} R_{t}+w_{t}+\frac{1}{1-\alpha}\left(\frac{y}{y+\phi} y_{t}-k_{t}+\frac{\alpha}{1-\alpha} \mu \Upsilon_{t}+\mu_{z t}+\mu \Upsilon t\right)-\rho_{t}-\frac{1}{1-\alpha} u_{t}=0 \\
& {\left[\mu \curlyvee \mu_{z^{*}}-(1-\delta)\right] i_{t}-\left\{\mu \curlyvee \mu_{z^{*}} k_{t+1}-(1-\delta)\left[k_{t}-\frac{1}{1-\alpha} \mu r_{t}-\mu_{z t}\right]\right\}=0} \\
& \mathbb{E}\left[\beta\left(\pi_{t+1}-\pi_{t}\right)-\gamma s_{t}-\left(\pi_{t}-\pi_{t-1}\right) \mid \Omega_{t}^{p}\right]=0 \\
& c_{t}-\frac{R}{(R-1)\left(2+\sigma_{\eta}\right)} R_{t}-q_{t}=0 \\
& \mathbb{E}\left\{-\left(\frac{1}{c\left(1-b \mu_{z^{*}}^{-1}\right.}\right)^{2}\left[c c_{t}-\frac{b c}{\mu_{z^{*}}} c_{t-1}+\frac{b c}{\mu_{z^{*}}}\left(\frac{\alpha}{1-\alpha} \mu_{\curlyvee t}+\mu_{z t}\right)\right]+\right. \\
& \beta\left(\frac{1}{c\left(1-b \mu_{z^{*}}^{-1}\right.}\right)^{2}\left[c c_{t+1}-\frac{b c}{\mu_{z^{*}}} c_{t}+\frac{b c}{\mu_{z^{*}}}\left(\frac{\alpha}{1-\alpha} \mu{ }_{t+1}+\mu_{z t+1}\right)\right]- \\
& \left.\lambda_{z^{*}}\left[(1+\eta(V))+\eta^{\prime}(V) V\right] \lambda_{z^{*} t}-\lambda_{z^{*}}\left[2+\frac{\eta^{\prime \prime}(V) V}{\eta^{\prime}(V)}\right] \eta^{\prime}(V) V\left(c_{t}-q_{t}\right) \mid \Omega_{t}^{p}\right\}=0 \\
& \mathbb{E}\left[-\lambda_{z^{*} t}+\lambda_{z^{*} t+1}+R_{t+1}-\pi_{t+1}-\frac{\alpha}{1-\alpha} \mu_{\Upsilon t+1}-\mu_{z t+1} \mid \Omega_{t}^{p}\right]=0 \\
& \frac{\xi_{w}\left(\lambda_{w} \sigma_{L}-\left(1-\lambda_{w}\right)\right)}{\left(1-\xi_{w}\right)\left(1-\beta \xi_{w}\right)}\left\{w_{t-1}+\left[-\frac{1+\beta \xi_{w}^{2}}{\xi_{w}}+\sigma_{L} \lambda_{w} \frac{\left(1-\xi_{w}\right)\left(1-\beta \xi_{w}\right)}{\xi_{w}\left(\lambda_{w} \sigma_{L}-\left(1-\lambda_{w}\right)\right)}\right] w_{t}+\beta w_{t+1}+\pi_{t-1}+\pi_{t}+\beta \pi_{t+1}+\right. \\
& \left.\frac{\left(1-\xi_{w}\right)\left(1-\beta \xi_{w}\right)\left(1-\lambda_{w}\right)}{\xi_{w}\left(\lambda_{w} \sigma_{L}-\left(1-\lambda_{w}\right)\right)}\left(-\sigma_{L} h_{t}+\lambda_{z^{*} t}\right)-(1-\vartheta) \mu_{z t}+\beta(1-\vartheta) \frac{\alpha}{1-\alpha} \mu_{\Upsilon t+1}+\beta(1-\vartheta) \mu_{z t+1}\right\}=0 \\
& (1+\eta) c c_{t}+\eta^{\prime} \frac{c^{2}}{q}\left(c_{t}-q_{t}\right)+i i_{t}-(y+\phi)\left[\alpha\left(u_{t} k_{t}-\frac{1}{1-\alpha} \mu_{\Upsilon}-\mu_{z t}\right)+(1-\alpha) h_{t}\right]+\rho \frac{k}{\mu_{z^{*}} \mu \curlyvee} u_{t}=0 \\
& w_{t}+h_{t}-\frac{x m\left(x_{t}+m_{t}\right)-q q_{t}}{x m-q}=0 \\
& x_{z t}+x_{\Upsilon_{t}}+x_{M t}-x_{t}=0 \\
& x_{t-1}-\pi_{t}-\frac{\alpha}{1-\alpha} \mu \Upsilon_{t}-\mu_{z t}+m_{t-1}-m_{t}=0 \\
& y y_{t}-(y+\phi)\left[\alpha\left(u_{t}+k_{t}-\frac{1}{1-\alpha} \mu \mu_{t}-\mu_{z t}\right)+(1-\alpha) h_{t}\right]+\rho \frac{k}{\mu_{z^{*}} \mu_{\curlyvee}} u_{t}=0 \\
& \mathbb{E}\left[u_{t}-\frac{1}{\sigma_{a}} \rho_{t} \mid \Omega_{t}^{p}\right]=0
\end{aligned}
$$


In this system, there are three shocks, $\left\{\epsilon_{M t}, \epsilon_{\mu_{z} t}, \epsilon_{\mu \curlyvee t}\right\}$, which are shocks to monetary policy, neutral technology, and embodied investment technology. The processes for various shocks are

$$
\begin{aligned}
\mu_{z t} & =\rho_{\mu z} \mu_{z t-1}+\epsilon_{\mu_{z} t} \\
\mu_{\Upsilon t} & =\rho_{\mu \curlyvee} \mu_{\Upsilon t-1}+\epsilon_{\mu \curlyvee t} \\
x_{M t} & =\rho_{M} x_{M t-1}+\epsilon_{M t} \\
x_{z t} & =\rho_{x z} x_{z t-1}+c_{z}^{p} \epsilon_{\mu_{z} t-1}+c_{z} \epsilon_{\mu_{z} t} \\
x_{\Upsilon t} & =\rho_{x \curlyvee} x_{\Upsilon t-1}+c_{\Upsilon}^{p} \epsilon_{\mu \curlyvee t-1}+c_{\curlyvee} \epsilon_{\mu \curlyvee t}
\end{aligned}
$$

In the estimation, we choose the parameters to minimize the distance between model-implied impulse responses and their data counterparts, as in Altig et al. (2011).

\section{A.1 Additional Tables for the Estimation of the Altig et al. (2011) Economies}

In this subsection, we included additional tables which show results discussed in Section 5. Table A-1 contains the estimated parameters under alternative wage markups and different sizes of the innovations to the impulse response functions. Table A-2 and Table A-3 display the results for the statistical properties of labor with the demand-determined solution and the approximated Drèze solution under different parameterization. 
Table A-1: Estimated Parameter Values for the Drèze Equilibria under Various Markups and Shock Sizes

\begin{tabular}{|c|c|c|c|c|c|c|c|}
\hline & \multirow{2}{*}{$\begin{array}{l}\text { Demand } \\
\text { Determined }\end{array}$} & \multicolumn{2}{|c|}{ Drèze, $5 \%$ markup } & \multicolumn{2}{|c|}{ Drèze, $10 \%$ markup } & \multicolumn{2}{|c|}{ Drèze, $15 \%$ markup } \\
\hline & & $1 \mathrm{std}$ & $1.5 \mathrm{std}$ & $2.5 \mathrm{std}$ & $3 \mathrm{std}$ & $3 \mathrm{std}$ & 4 std \\
\hline$\rho_{\mu_{z}}$ & $\begin{array}{c}0.902 \\
(0.102)\end{array}$ & $\begin{array}{c}0.697 \\
(0.240)\end{array}$ & $\begin{array}{c}0.579 \\
(0.002)\end{array}$ & $\begin{array}{c}0.824 \\
(0.119)\end{array}$ & $\begin{array}{l}0.736 \\
(0.183)\end{array}$ & $\begin{array}{c}0.902 \\
(0.112)\end{array}$ & $\begin{array}{l}0.898 \\
(0.063)\end{array}$ \\
\hline$\sigma_{\mu z}$ & $\begin{array}{c}0.068 \\
(0.046)\end{array}$ & $\begin{array}{c}0.140 \\
(0.089)\end{array}$ & $\begin{array}{c}0.110 \\
(0.000)\end{array}$ & $\begin{array}{c}0.112 \\
(0.055)\end{array}$ & $\begin{array}{c}0.132 \\
(0.071)\end{array}$ & $\begin{array}{c}0.070 \\
(0.035)\end{array}$ & $\begin{array}{c}0.089 \\
(0.035)\end{array}$ \\
\hline$\rho_{M}$ & $\begin{array}{l}-0.037 \\
(0.111)\end{array}$ & $\begin{array}{l}-0.040 \\
(0.130)\end{array}$ & $\begin{array}{l}-0.078 \\
(0.121)\end{array}$ & $\begin{array}{l}-0.019 \\
(0.148)\end{array}$ & $\begin{array}{l}-0.018 \\
(0.125)\end{array}$ & $\begin{array}{l}-0.030 \\
(0.123)\end{array}$ & $\begin{array}{c}-0.021 \\
(0.131)\end{array}$ \\
\hline$\sigma_{M}$ & $\begin{array}{l}0.331 \\
(0.084)\end{array}$ & $\begin{array}{l}0.325 \\
(0.078)\end{array}$ & $\begin{array}{l}0.319 \\
(0.074)\end{array}$ & $\begin{array}{l}0.339 \\
(0.077)\end{array}$ & $\begin{array}{l}0.331 \\
(0.077)\end{array}$ & $\begin{array}{l}0.334 \\
(0.075)\end{array}$ & $\begin{array}{l}0.332 \\
(0.077)\end{array}$ \\
\hline$\rho_{\mu \curlyvee}$ & $\begin{array}{l}0.241 \\
(0.224)\end{array}$ & $\begin{array}{c}0.318 \\
(0.176)\end{array}$ & $\begin{array}{l}0.344 \\
(0.377)\end{array}$ & $\begin{array}{l}0.841 \\
(0.138)\end{array}$ & $\begin{array}{c}0.839 \\
(0.146)\end{array}$ & $\begin{array}{c}0.833 \\
(0.178)\end{array}$ & $\begin{array}{l}0.840 \\
(0.143)\end{array}$ \\
\hline$\sigma_{\mu} \Upsilon$ & $\begin{array}{l}0.303 \\
(0.042)\end{array}$ & $\begin{array}{l}0.286 \\
(0.046)\end{array}$ & $\begin{array}{l}0.287 \\
(0.046)\end{array}$ & $\begin{array}{l}0.296 \\
(0.053)\end{array}$ & $\begin{array}{l}0.297 \\
(0.053)\end{array}$ & $\begin{array}{l}0.304 \\
(0.051)\end{array}$ & $\begin{array}{l}0.296 \\
(0.053)\end{array}$ \\
\hline$\rho_{x z}$ & $\begin{array}{l}0.343 \\
(0.266)\end{array}$ & $\begin{array}{l}0.195 \\
(0.480)\end{array}$ & $\begin{array}{l}0.130 \\
(0.553)\end{array}$ & $\begin{array}{l}0.315 \\
(0.380)\end{array}$ & $\begin{array}{l}0.251 \\
(0.413)\end{array}$ & $\begin{array}{l}0.347 \\
(0.285)\end{array}$ & $\begin{array}{l}0.356 \\
(0.338)\end{array}$ \\
\hline$c_{z}$ & $\begin{array}{l}2.997 \\
(2.310)\end{array}$ & $\begin{array}{l}1.027 \\
(0.749)\end{array}$ & $\begin{array}{l}1.008 \\
(0.704)\end{array}$ & $\begin{array}{l}1.435 \\
(0.875)\end{array}$ & $\begin{array}{l}1.108 \\
(0.717)\end{array}$ & $\begin{array}{l}2.840 \\
(1.823)\end{array}$ & $\begin{array}{l}2.023 \\
(1.124)\end{array}$ \\
\hline$c_{z}^{p}$ & $\begin{array}{c}1.327 \\
(1.381)\end{array}$ & $\begin{array}{c}0.665 \\
(0.650)\end{array}$ & $\begin{array}{c}0.715 \\
(0.724)\end{array}$ & $\begin{array}{c}0.697 \\
(0.551)\end{array}$ & $\begin{array}{c}0.598 \\
(0.427)\end{array}$ & $\begin{array}{c}1.373 \\
(0.974)\end{array}$ & $\begin{array}{c}0.946 \\
(0.717)\end{array}$ \\
\hline$c_{\Upsilon}^{p}$ & $\begin{array}{c}0.135 \\
(0.238)\end{array}$ & $\begin{array}{c}0.107 \\
(0.244)\end{array}$ & $\begin{array}{l}0.110 \\
(0.270)\end{array}$ & $\begin{array}{c}0.149 \\
(0.247)\end{array}$ & $\begin{array}{c}0.133 \\
(0.247)\end{array}$ & $\begin{array}{l}0.125 \\
(0.247)\end{array}$ & $\begin{array}{c}0.150 \\
(0.244)\end{array}$ \\
\hline$\rho_{x} \Upsilon$ & $\begin{array}{c}0.824 \\
(0.154)\end{array}$ & $\begin{array}{l}0.832 \\
(0.132)\end{array}$ & $\begin{array}{c}0.882 \\
(0.066)\end{array}$ & $\begin{array}{c}0.841 \\
(0.138)\end{array}$ & $\begin{array}{c}0.839 \\
(0.146)\end{array}$ & $\begin{array}{l}0.833 \\
(0.178)\end{array}$ & $\begin{array}{c}0.840 \\
(0.143)\end{array}$ \\
\hline$c_{\curlyvee}$ & $\begin{array}{c}0.246 \\
(0.244)\end{array}$ & $\begin{array}{l}0.305 \\
(0.266)\end{array}$ & $\begin{array}{l}0.318 \\
(0.276)\end{array}$ & $\begin{array}{l}0.226 \\
(0.253)\end{array}$ & $\begin{array}{l}0.240 \\
(0.250)\end{array}$ & $\begin{array}{l}0.224 \\
(0.230)\end{array}$ & $\begin{array}{l}0.221 \\
(0.245)\end{array}$ \\
\hline$\epsilon$ & $\begin{array}{c}0.808 \\
(0.208)\end{array}$ & $\begin{array}{l}0.779 \\
(0.193)\end{array}$ & $\begin{array}{l}0.722 \\
(0.170)\end{array}$ & $\begin{array}{l}0.823 \\
(0.208)\end{array}$ & $\begin{array}{c}0.799 \\
(0.208)\end{array}$ & $\begin{array}{l}0.818 \\
(0.193)\end{array}$ & $\begin{array}{c}0.796 \\
(0.199)\end{array}$ \\
\hline$S^{\prime \prime}$ & $\begin{array}{c}3.281 \\
(2.038)\end{array}$ & $\begin{array}{l}4.275 \\
(2.378)\end{array}$ & $\begin{array}{c}3.246 \\
(2.030)\end{array}$ & $\begin{array}{l}4.539 \\
(2.462)\end{array}$ & $\begin{array}{l}4.257 \\
(2.252)\end{array}$ & $\begin{array}{c}3.216 \\
(1.758)\end{array}$ & $\begin{array}{l}4.252 \\
(2.623)\end{array}$ \\
\hline$\xi_{w}$ & $\begin{array}{c}0.722 \\
(0.123)\end{array}$ & $\begin{array}{l}0.825 \\
(0.043)\end{array}$ & $\begin{array}{l}0.801 \\
(0.135)\end{array}$ & $\begin{array}{l}0.850 \\
(0.036)\end{array}$ & $\begin{array}{c}0.854 \\
(0.050)\end{array}$ & $\begin{array}{l}0.806 \\
(0.096)\end{array}$ & $\begin{array}{c}0.872 \\
(0.040)\end{array}$ \\
\hline$b$ & $\begin{array}{c}0.706 \\
(0.045)\end{array}$ & $\begin{array}{l}0.698 \\
(0.058)\end{array}$ & $\begin{array}{c}0.719 \\
(0.078)\end{array}$ & $\begin{array}{l}0.717 \\
(0.051)\end{array}$ & $\begin{array}{c}0.711 \\
(0.055)\end{array}$ & $\begin{array}{l}0.717 \\
(0.042)\end{array}$ & $\begin{array}{c}0.721 \\
(0.046)\end{array}$ \\
\hline$\sigma_{a}$ & $\begin{array}{l}1.995 \\
(2.222)\end{array}$ & $\begin{array}{l}4.564 \\
(7.070)\end{array}$ & $\begin{array}{l}0.932 \\
(0.834)\end{array}$ & $\begin{array}{c}3.373 \\
(3.627)\end{array}$ & $\begin{array}{c}3.688 \\
(4.297)\end{array}$ & $\begin{array}{l}1.744 \\
(2.414)\end{array}$ & $\begin{array}{c}3.075 \\
(3.410)\end{array}$ \\
\hline$\gamma$ & $\begin{array}{l}0.040 \\
(0.029)\end{array}$ & $\begin{array}{l}0.054 \\
(0.039)\end{array}$ & $\begin{array}{l}0.103 \\
(0.144)\end{array}$ & $\begin{array}{l}0.060 \\
(0.036)\end{array}$ & $\begin{array}{l}0.057 \\
(0.039)\end{array}$ & $\begin{array}{l}0.041 \\
(0.026)\end{array}$ & $\begin{array}{l}0.059 \\
(0.037)\end{array}$ \\
\hline
\end{tabular}


Table A-2: Effects on Labor of Shocks over Each Solution Concept: 10\% Markup, 3 Std Shock

\begin{tabular}{|c|c|c|c|c|c|c|c|c|}
\hline & \multicolumn{4}{|c|}{$\begin{array}{l}\text { Estimated with } \\
\text { Demand-Determined }\end{array}$} & \multicolumn{4}{|c|}{$\begin{array}{c}\text { Estimated with } \\
\text { Approximated Drèze: } 3 \text { std shock }\end{array}$} \\
\hline & mean & var & $\begin{array}{l}\text { corr with } \\
\text { output }\end{array}$ & $\begin{array}{l}\% \text { labor } \\
\text { violation }\end{array}$ & mean & var & $\begin{array}{l}\text { corr with } \\
\text { output }\end{array}$ & $\begin{array}{l}\% \text { labor } \\
\text { violation }\end{array}$ \\
\hline \multicolumn{9}{|c|}{ Neutral Technology Shock } \\
\hline Demand-Determined & - & 0.17 & 0.86 & 3.50 & - & 0.23 & 0.97 & 5.57 \\
\hline Approximated Drèze & -0.44 & 0.25 & 0.85 & - & -0.83 & 0.35 & 0.87 & - \\
\hline \multicolumn{9}{|c|}{ Investment Technology Shock } \\
\hline Demand-Determined & - & 0.62 & 0.99 & 0.90 & - & 0.47 & 0.99 & 1.04 \\
\hline Approximated Drèze & -0.03 & 0.55 & 0.99 & - & -0.05 & 0.43 & 0.99 & - \\
\hline \multicolumn{9}{|l|}{ Monetary Shock } \\
\hline Demand-Determined & - & 0.50 & 0.99 & 0.05 & - & 0.36 & 1.00 & 0.00 \\
\hline Approximated Drèze & 0.01 & 0.50 & 0.99 & 一 & 0.00 & 0.36 & 1.00 & - \\
\hline \multicolumn{9}{|l|}{ All Shocks } \\
\hline Demand-Determined & - & 1.35 & 0.96 & 5.58 & - & 1.12 & 0.95 & 7.59 \\
\hline Approximated Drèze & -0.74 & 0.99 & 0.94 & - & -1.21 & 0.95 & 0.92 & - \\
\hline
\end{tabular}

Notes: All the variables except for the mean of labor are logged and HP filtered. 
Table A-3: Effects on Labor of Shocks over Each Solution Concept: 15\% Markup, 4 Std Shock

\begin{tabular}{|c|c|c|c|c|c|c|c|c|}
\hline & \multicolumn{4}{|c|}{$\begin{array}{l}\text { Estimated with } \\
\text { Demand-Determined }\end{array}$} & \multicolumn{4}{|c|}{$\begin{array}{l}\text { Estimated with } \\
\text { Approximated Drèze: } 4 \text { std shock }\end{array}$} \\
\hline & mean & var & $\begin{array}{c}\text { corr with } \\
\text { output }\end{array}$ & $\begin{array}{l}\% \text { labor } \\
\text { violation }\end{array}$ & mean & var & $\begin{array}{c}\text { corr with } \\
\text { output }\end{array}$ & $\begin{array}{l}\% \text { labor } \\
\text { violation }\end{array}$ \\
\hline \multicolumn{9}{|c|}{ Neutral Technology Shock } \\
\hline Demand-Determined & - & 0.17 & 0.86 & 1.21 & - & 0.09 & 0.94 & 3.68 \\
\hline Approximated Drèze & -0.14 & 0.17 & 0.84 & 一 & -0.71 & 0.23 & 0.83 & - \\
\hline \multicolumn{9}{|c|}{ Investment Technology Shock } \\
\hline Demand-Determined & - & 0.62 & 0.99 & 0.06 & - & 0.47 & 0.99 & 0.11 \\
\hline Approximated Drèze & 0.01 & 0.62 & 0.99 & - & 0.00 & 0.46 & 0.99 & - \\
\hline \multicolumn{9}{|l|}{ Monetary Shock } \\
\hline Demand-Determined & - & 0.50 & 0.99 & 0.00 & - & 0.36 & 1.00 & 0.00 \\
\hline Approximated Drèze & 0.01 & 0.50 & 0.99 & - & 0.00 & 0.36 & 1.00 & - \\
\hline \multicolumn{9}{|l|}{ All Shocks } \\
\hline Demand-Determined & - & 1.35 & 0.96 & 2.28 & - & 0.98 & 0.94 & 4.92 \\
\hline Approximated Drèze & -0.25 & 1.11 & 0.95 & - & -0.97 & 0.90 & 0.93 & - \\
\hline
\end{tabular}

Notes: All the variables except for the mean of labor are logged and HP filtered. 


\section{B Details of the Estimation of the Smets and Wouters (2007)}

The system of the log-linearized equations for estimation and simulation are the following (the only changes from Smets and Wouters (2007) are in equations (A-22) and (A-30)):

$$
\begin{aligned}
y_{t} & =c_{y} c_{t}+i_{y} i_{t}+k_{y} \bar{r}^{k} u_{t}+\epsilon_{t}^{g} \\
c_{t} & =\frac{h / \zeta}{1+h / \zeta} c_{t-1}+\frac{1}{1+h / \zeta} \mathbb{E}_{t} c_{t+1}-\frac{1-h / \zeta}{1+h / \zeta}\left(r_{t}-E_{t} \pi_{t+1}+\epsilon_{t}^{b}\right) \\
i_{t} & =\frac{1}{1+\beta}\left(i_{t-1}+\beta \mathbb{E}_{t} i_{t+1}+\frac{1}{\zeta^{2} \varphi} q_{t}\right)+\epsilon_{t}^{i} \\
q_{t} & =\frac{\bar{r}^{k}}{1-\delta+\bar{r}^{k}} r_{t+1}^{k}+\frac{1-\delta}{1-\delta+\bar{r}^{k}} \mathbb{E}_{t} q_{t+1}-\left(r_{t}-\mathbb{E}_{t} \pi_{t+1}+\epsilon_{t}^{b}\right) \\
y_{t} & =\Phi\left(\alpha\left(k_{t-1}+u_{t}\right)+(1-\alpha) \ell_{t}+\epsilon_{t}^{a}\right) \\
r_{t}^{k} & =\frac{1-\psi}{\psi} u_{t} \\
k_{t} & =\left(1-\frac{1-\delta}{\zeta}\right) k_{t-1}+\frac{1-\delta}{\zeta} i_{t}+\epsilon_{t}^{i} \\
\pi_{t} & =\frac{1}{1+\beta \iota_{p}}\left(\iota_{p} \pi_{t-1}+\beta \mathbb{E}_{t} \pi_{t+1}+\frac{\left(1-\xi_{p}\right)\left(1-\beta \xi_{p}\right)}{\xi_{p}\left((\Phi-1) \varepsilon_{p}+1\right)}\left(\alpha\left(k_{t-1}+u_{t}-\ell_{t}\right)-w_{t}+\epsilon_{t}^{a}\right)\right)+\epsilon_{t}^{p} \\
r_{t}^{k} & =w_{t}+\ell_{t}-k_{t-1}-u_{t} \\
w_{t} & =\frac{1}{1+\beta}\left\{\beta \mathbb{E}_{t}\left[w_{t+1}\right]+w_{t-1}+\beta \mathbb{E}_{t}\left[\pi_{t+1}\right]-\left(1+\beta \iota_{w}\right) \pi_{t}+\iota_{w} \pi_{t-1}\right. \\
& \left.+\frac{\left(1-\beta \xi_{w}\right)\left(1-\xi_{w}\right)}{\left(1+\gamma \epsilon_{w}\right) \xi_{w}}\left(\gamma \ell_{t}+\frac{1}{1-h / \zeta} c_{t}-\frac{h / \zeta}{(1-h / \zeta} c_{t-1}-w_{t}\right)\right\}+\epsilon_{t}^{w} \\
r_{t} & =\rho r_{t-1}+(1-\rho)\left(r_{\pi} \pi_{t}+r_{y}\left(y_{t}-y_{t}^{p}\right)\right)+r_{\Delta y}\left(y_{t}-y_{t}^{p}-\left(y_{t-1}-y_{t-1}^{p}\right)\right)+\epsilon_{t}^{m}
\end{aligned}
$$

In this system, there are seven shocks, $\left\{\epsilon_{t}^{a}, \epsilon_{t}^{i}, \epsilon_{t}^{b}, \epsilon_{t}^{p}, \epsilon_{t}^{w}, \epsilon_{t}^{g}, \epsilon_{t}^{m}\right\}$, which are shocks to TFP, investment technology, risk premium, price markup, wage markup, government spending, and monetary policy. Some of the shocks are rescaled to facilitate estimation. The processes for various shocks are

$$
\begin{aligned}
\epsilon_{t}^{g} & =\rho_{g} \epsilon_{t-1}^{g}+\eta_{t}^{g}+\rho_{g a} \eta_{t}^{a} \\
\epsilon_{t}^{b} & =\rho_{b} \epsilon_{t-1}^{b}+\eta_{t}^{b} \\
\epsilon_{t}^{i} & =\rho_{i} \epsilon_{t-1}^{i}+\eta_{t}^{i} \\
\epsilon_{t}^{a} & =\rho_{a} \epsilon_{t-1}^{a}+\eta_{t}^{a} \\
\epsilon_{t}^{m} & =\rho_{m} \epsilon_{t-1}^{m}+\eta_{t}^{m} \\
\epsilon_{t}^{p} & =\rho_{p} \epsilon_{t-1}^{p}+\eta_{t}^{p}-\mu_{p} \eta_{t-1}^{p} \\
\epsilon_{t}^{w} & =\rho_{w} \epsilon_{t-1}^{w}+\eta_{t}^{w}-\mu_{w} \eta_{t-1}^{w}
\end{aligned}
$$


As in Smets and Wouters (2007), we fixed a few parameters, which are the depreciation rate $\delta=0.025$, the average government spending to output ratio $g_{y}=0.18$, the Kimball aggregator parameter $\varepsilon_{p}=10$, and we use log utility function for consumption. Although Smets and Wouters (2007) set the wage markup to $50 \%$, we estimate the model for various other wage markup levels and report them in Table A-4. The process for the shocks is reported in Table A-5.

Table A-4: Smets and Wouters (2007) Model: Structural Parameters

\begin{tabular}{lccc}
\hline \hline Wage markup, $\frac{\epsilon_{w}}{\epsilon_{w}-1}$ & $5 \%$ & $10 \%$ & $15 \%$ \\
\hline Investment adjustment cost, $\varphi$ & 5.409 & 5.425 & 5.430 \\
Habit formation, $h$ & 0.778 & 0.784 & 0.787 \\
Wage Calvo probability, $\xi_{w}$ & 0.527 & 0.576 & 0.605 \\
Inverse Frsich elasticity, $\gamma$ & 2.873 & 2.811 & 2.772 \\
Price Calvo probability, $\xi_{p}$ & 0.681 & 0.667 & 0.659 \\
Wage indexation, $\iota_{w}$ & 0.571 & 0.583 & 0.589 \\
Price indexation, $\iota_{p}$ & 0.212 & 0.216 & 0.218 \\
Utilization elasticity, $\psi$ & 0.535 & 0.537 & 0.538 \\
Fixed cost, $\Phi$ & 1.555 & 1.560 & 1.562 \\
Share of capital in production, $\alpha$ & 0.189 & 0.190 & 0.190 \\
Monetary policy for inflation, $r_{\pi}$ & 1.895 & 1.907 & 1.913 \\
Monetary policy for output gap, $r_{y}$ & 0.069 & 0.070 & 0.071 \\
Monetary policy persistency, $\rho$ & 0.812 & 0.808 & 0.805 \\
Monetary policy for output gap change, $r_{\Delta y}$ & 0.233 & 0.229 & 0.227 \\
Trend, $\zeta$ & 1.004 & 1.004 & 1.004 \\
Discount rate, $\beta$ & 0.998 & 0.998 & 0.998 \\
\hline \hline
\end{tabular}

Notes: The specification of the prior distribution is the same as in Smets and Wouters (2007). We only report the posterior modes of the structural parameters in this table for various wage markup levels. The posterior means are not included here but are available upon request. When we simulate the model, we use the posterior modes of the structural parameters.

We make two further modifications to Smets and Wouters (2007), in line with most of the recent literature: the utility function is additively separable in consumption and leisure, and the aggregator of labor inputs is the standard Dixit-Stiglitz aggregator. 
Table A-5: Smets and Wouters (2007) Model: Persistence and Standard Deviation of Various Shocks

\begin{tabular}{lccc}
\hline \hline Wage markup, $\frac{\epsilon_{w}}{\epsilon_{w}-1}$ & $5 \%$ & $10 \%$ & $15 \%$ \\
\hline Government spending shock, $\epsilon^{g}$ & 0.517 & 0.517 & 0.518 \\
Government spending shock, $\rho_{g}$ & 0.972 & 0.971 & 0.971 \\
Government spending shock, $\rho_{g a}$ & 0.537 & 0.536 & 0.536 \\
Risk premium shock, $\epsilon^{b}$ & 0.218 & 0.223 & 0.226 \\
Risk premium shock, $\rho_{b}$ & 0.373 & 0.347 & 0.333 \\
Investment shock, $\epsilon^{i}$ & 0.377 & 0.385 & 0.389 \\
Investment shock, $\rho_{i}$ & 0.768 & 0.757 & 0.752 \\
TFP shock, $\epsilon^{a}$ & 0.459 & 0.458 & 0.458 \\
TFP shock, $\rho_{a}$ & 0.950 & 0.950 & 0.949 \\
Monetary policy shock, $\epsilon^{m}$ & 0.239 & 0.240 & 0.240 \\
Monetary policy shock, $\rho_{m}$ & 0.125 & 0.132 & 0.136 \\
Price markup shock, $\epsilon^{p}$ & 0.142 & 0.142 & 0.142 \\
Price markup shock, $\rho_{p}$ & 0.901 & 0.906 & 0.908 \\
Price markup shock, $\mu_{p}$ & 0.748 & 0.746 & 0.746 \\
Wage markup shock, $\epsilon^{w}$ & 0.248 & 0.248 & 0.248 \\
Wage markup shock, $\rho_{w}$ & 0.972 & 0.975 & 0.977 \\
Wage markup shock, $\mu_{w}$ & 0.927 & 0.916 & 0.908 \\
Implied true wage markup shock, $\widehat{\epsilon}^{w}$ & 71.275 & 50.573 & 42.544 \\
\hline \hline Notes: The specication of the $p r i s$ & & & \\
\hline
\end{tabular}

Notes: The specification of the prior distribution is the same as in Smets and Wouters (2007). We only report the posterior modes of the shock processes in this table for various wage markup levels. The posterior means are not included here but are available upon request. When we simulate the model, we use the posterior modes of the shock processes. 


\section{Analysis of Galí et al. (2012)}

Galí et al. (2012) set the steady-state wage markup level to $18 \%$, which via equation (12) implies a Frisch elasticity of 0.25 . The approach in Galí et al. (2012) allows to separately identify labor supply shocks and wage markup shocks, and the estimated standard deviation of the wage markup shock is much smaller than that of Smets and Wouters (2007) (0.04 versus 0.25$).{ }^{19}$. Table A- 6 shows the comparison between demand-determined labor and the voluntary ex-post labor. The pattern is broadly consistent with the findings in Section 3.2. The main difference is the role played by the wage markup shocks become smaller, and the violation of the labor supply constraint becomes less severe, even though the two series are still significantly different from each other.

Although the Galí et al. (2012) estimate of the standard deviation of the wage markup shock is much smaller than that of Smets and Wouters (2007) (0.04 versus 0.25). Table A- 6 shows the comparison between demand-determined labor and the voluntary ex-post labor. The pattern is broadly consistent with the findings in Section 3.2. The main difference is the role played by the wage markup shocks become smaller, and the violation of the labor supply constraint becomes less severe, even though the two series are still significantly different from each other.

Table A-6: Galí et al. (2012) with 18\% Wage Markup

\begin{tabular}{lccccccccc}
\hline \hline & \multicolumn{3}{c}{ with Wage Markup Shock } & \multicolumn{3}{c}{ w/o Wage Markup Shock } \\
& mean & var $\begin{array}{c}\text { corr with } \\
\text { output }\end{array}$ & $\begin{array}{c}\text { \% labor } \\
\text { violation }\end{array}$ & mean & var & $\begin{array}{c}\text { corr with } \\
\text { output }\end{array}$ & $\begin{array}{c}\text { labor } \\
\text { violation }\end{array}$ \\
\hline $\begin{array}{l}\text { Demand-Determined } \\
\text { Voluntary Ex-Post }\end{array}$ & -0.57 & 0.56 & 0.59 & - & -0.13 & 0.39 & 0.69 & - \\
\hline
\end{tabular}

Notes: All the variables except for the mean of labor are logged and HP filtered.

\footnotetext{
${ }^{19}$ In the simulation, it still generates negative wage markup from time to time.
} 


\section{Details of the Computation of the Staggered Wage Economy}

We use a policy function iteration method to obtain the numerical solution. The system of equations that characterizes the solution is

$$
\begin{aligned}
c_{t}^{-\sigma} & =\beta \mathbb{E}_{t}\left[c_{t+1}^{-\sigma} \frac{R_{t}}{\pi_{t+1}}\right] \\
c_{t}^{-\sigma} & =\beta \mathbb{E}_{t}\left[c_{t+1}^{-\sigma} \frac{1+r_{t+1}^{k}-\delta}{\pi_{t+1}}\right] \\
\frac{r_{t}^{k}}{p_{t}} & =\alpha z_{t} k_{t}^{\alpha-1} e_{t}^{1-\alpha}, \\
\log R_{t} & =\log \frac{1}{\beta}+\phi_{\pi} \pi_{t}+\phi_{y} \log \frac{y_{t}}{y^{*}}+\eta_{t}, \\
c_{t}+k_{t+1} & =y_{t}+(1-\delta) k_{t} \\
y_{t} & =z_{t} k_{t}^{\alpha} e_{t}^{1-\alpha}, \\
e_{t} & =\left[\sum_{i=0}^{T_{w}} e_{i, t}^{\frac{\epsilon_{w}-1}{\epsilon_{w}}}\right]^{\frac{\epsilon_{w}}{\epsilon_{w}-1}}, \\
e_{i, t} & =\min \left\{\left[\frac{w_{t-i}^{*}}{(1-\alpha) z_{t} k_{t}^{\alpha} e_{t}^{-\alpha} p_{t}}\right]^{-\epsilon_{w}} e_{t},\left(\frac{u^{\prime}\left(c_{t}\right) w_{t-i}^{*}}{\phi p_{t}}\right)^{\frac{1}{\gamma}}\right\} .
\end{aligned}
$$

In addition, the optimization problem (27) to (28) is also part of the system.

There are two differences between the demand-determined economy and the Drèze equilibrium: first, the

employment is determined by the minimum of the demand and supply in the Drèze equilibrium (see equation (A-46)), whereas in the demand-determined economy, employment always equals to labor demand. Second, the choice of the optimal nominal wage, $w_{t}^{*}$, cannot be characterized by a simple first-order condition because of the potential binding labor supply constraint. In the computation, we have to use a global search method to find the optimal wage choice.

We look for policy functions for $\left\{k_{t+1}, c_{t}, y_{t}, e_{i, t}, e_{t}, w_{t}^{*}, \pi_{t}, R_{t}\right\}$. The state variables at period $t$ include the following: the current technology shock $z_{t}$ or the monetary shock $\eta_{t}$, the capital stock $k_{t}$, and the wages set in the previous three periods $\left\{\frac{w_{t-1}^{*}}{p_{t-1}}, \frac{w_{t-2}^{*}}{p_{t-1}}, \frac{w_{t-3}^{*}}{p_{t-1}}\right\}$.

\section{D.1 Note on Solving the Occasionally Binding Constraint Problem}

Guerrieri and lacoviello (2015) develop a Dynare toolkit that can solve DSGE models with occasionally binding constraints. In this subsection, we discuss why this method cannot be applied in our model.

Guerrieri and lacoviello (2015)'s method can handle problems with exogenous binding constraints such as 
non-negative investment, a zero-bound on the nominal interest rate, an exogenous borrowing constraint, and so on. In these cases, one can neatly partition the problem into two regions: in the first region, the constraint is not binding and one can use the first-order condition to characterize the solution. In the second region, the constraint is binding and one can simply set the variable to equal the constraint (for example, let the nominal interest rate be zero).

The problem in this paper is more involved. When the labor supply constraint is not binding, employment equals the labor demand, and the first-order condition can be applied as in the standard New Keynesian literature. When the labor supply constraint is binding, different from the examples listed earlier, the labor supply constraint is not an exogenous constraint because the level of the labor supply is endogenously determined. What makes this case even worse is that when the labor supply constraint is binding, the union's problem is not concave, which implies that we cannot use either the first-order condition or some exogenous value to determine the optimal wage (and hence employment).

Finally, the computation cost to apply Guerrieri and lacoviello (2015)'s method is not greatly affected by the number of state variables in the model but is increasing fast with the number of occasionally binding constraints. In Calvo-type sticky wage models, the number of occasionally binding constraints is infinite because there are infinitely many cohorts. In our simple economy with Taylor-type staggered wage contracts, there are four occasionally binding constraints, which is still a relatively large number.

To summarize, in our case, there is no simple way to decide the optimal level of wage and employment when labor supply is binding. Therefore, we solve the Drèze equilibrium using a global method. 